Russian Academy of Sciences, Far Eastern Branch

Botanical Garden-Institute

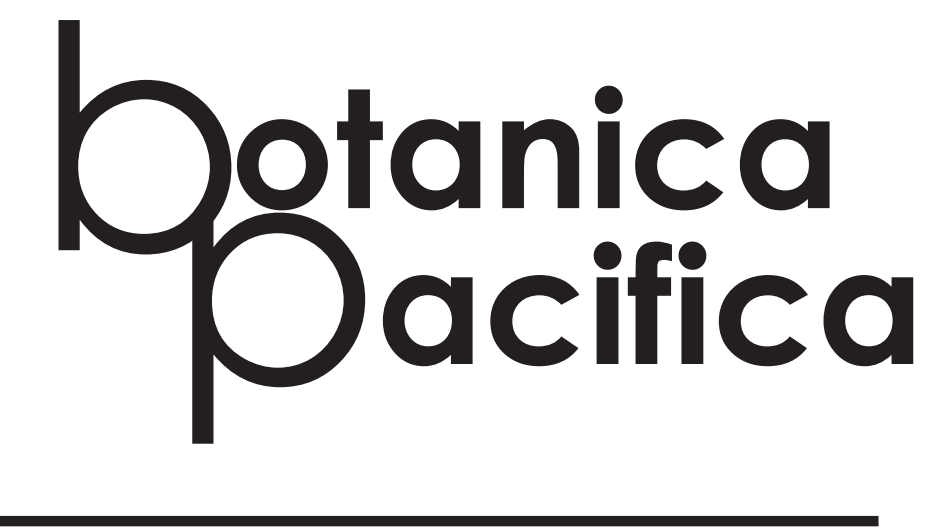

A JOURNAL OF PLANT SCIENCE
AND CONSERVATION

VOLUME 9, NO. 12020 


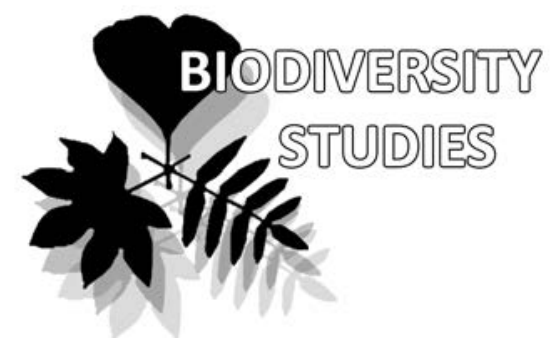

\title{
Findings to the flora of Russia and adjacent countries: New national and regional vascular plant records, 2
}

\author{
Alla V. Verkhozina*1, Olga A. Chernysheva ${ }^{1}$, Alexandr L. Ebel ${ }^{2}$, \\ Andrey S. Erst ${ }^{2,3}$, Nikolay V. Dorofeev ${ }^{1}$, Vladimir I. Dorofeyev ${ }^{4}$, \\ Alexey V. Grebenjuk ${ }^{4}$, Anna Ya. Grigorjevskaja ${ }^{5}$ Ziyarat A. \\ Guseinova $^{6}$, Anastasia V. Ivanova ${ }^{7}$, Anatoliy A. Khapugin ${ }^{8,9}$, Andrey \\ Yu. Korolyuk ${ }^{3}$, Kirill A. Korznikov ${ }^{10}$, Igor V. Kuzmin ${ }^{8}$, Maxim M. \\ Mallaliev $^{6}$, Vladislav V. Murashko ${ }^{1}$, Ramazan A. Murtazaliev ${ }^{6,11}$, \\ Ksenia B. Popova ${ }^{12}$, Irina N. Safronova ${ }^{4}$, Sergey V. Saksonov ${ }^{7}$, Lyudmi- \\ la I. Sarajeva ${ }^{13}$, Stepan A. Senator ${ }^{7}$, Victoria I. Troshkina ${ }^{3}$, Vladimir M. \\ Vasjukov $^{7}$, Wei Wang ${ }^{14,15}$, Kunli Xiang ${ }^{14,15}$, Evgenii G. Zibzeev ${ }^{3}$, Dmitry \\ V. Zolotov ${ }^{16}$, Elena Yu. Zykova ${ }^{3}$, Denis A. Krivenko
}

\footnotetext{
${ }^{1}$ Siberian Institute of Plant Physiology and Biochemistry SB RAS, Irkutsk, Russia

${ }^{2}$ National Research Tomsk State University, Tomsk, Russia

${ }^{3}$ Central Siberian Botanical Garden SB RAS, Novosibirsk, Russia

${ }^{4}$ Komarov Botanical Institute RAS, St. Petersburg, Russia

${ }^{5}$ Voronezh State University, Voronezh, Russia

${ }^{6}$ Mountain Botanical Garden, DSC RAS, Makhachkala, Russia

Institute of Ecology of the Volga River Basin of the RAS - Branch of Samara Federal Research Scientific Center of the RAS, Togliatti, Russia

${ }^{8}$ Tyumen State University, Tyumen, Russia

${ }^{9}$ Joint Directorate of the Mordovia

State Nature Reserve and National Park

"Smolny", Saransk, Russia

${ }^{10}$ Botanical Garden-Institute FEB RAS,

Vladivostok, Russia

${ }^{11}$ Dagestan State Medical University, Makhachkala, Russia

${ }^{12}$ M.V. Lomonosov Moscow State University, Moscow, Russia

${ }^{13}$ Daursky State Nature Biosphere Reserve, Nizhny Tsasuchey, Russia

${ }^{14}$ Institute of Botany, Chinese Academy of Sciences, Beijing, China

${ }^{15}$ University of Chinese Academy of Sciences, Beijing, China

${ }^{16}$ Institute for Water and Environmental Problems SB RAS
}

* corresponding author, allaverh@list.ru

Manuscript received: 17.03 .2020

Review completed: 05.05.2020

Accepted for publication: 12.05 .2020

Published online: 14.05.2020

\begin{abstract}
A B S T R A C T
With this paper we continue a new annual series, the main purpose of which is to make significant floristic findings from Russia and neighboring countries more visible in Russia and abroad. In total, this paper presents new records for 24 vascular plant species from 4 Eurasian countries, obtained during field explorations, as well as during taxonomic revisions of herbarium materials. For the first time, new locality of Ageratum conyzoides, Salvia hispanica, Thymus rasitatus, Tulipa mongolica is recorded for Russia, Sparganium glomeratum for North Korea, Alyssum armenum for Georgia, Thymus pseudopannonicus for Kazakhstan, Cymbalaria muralis for the Asian part of Russia, Anthemis ruthenica for Siberia, Capsella orientalis, Echinops sphaerocephalus, Heracleum sosnowskeyi, Thymus elegans for Eastern Siberia, Persicaria orientalis for Western Siberia, Galatella crinitoides for the Black Soil Region, Centaurea orientalis for Zavolzhye, Silene dichotoma for the Altai Republic, Onobrychis arenaria, Symphyotrichum squamatum, Verbesina encelioides for the Republic of Dagestan, Geranium daburicum for the Republic of Sakha (Yakutia), Koeleria spryginii for the Republic of Tatarstan, Phacelia tanacetifolia for Sakhalin, Adonis wolgensis for Novosibirsk Region. For each species, the general distribution, habitat, and taxonomy, indicating differences from related species and location are presented.
\end{abstract}

K e y w o r d s : floristic findings, taxonomy, Russia, Kazakhstan, Georgia, North Korea, Caucasus

\section{P E 3 Ю M E}

Верхозина А.В., Чернышева О.А., Эбель А.А., Эрст А.С., Аорофеев Н.В., Аорофеев В.И., Гребенюк А.В., Григорьевская А.Я., Гусейнова З.А., Иванова А.В., Хапугин А.А., Королюк А.Ю., Корзников К.А., Кузьмин И.В., Мамлалиев М.М., Мурашко В.В., Муртазалиев Р.А., Попова К.Б., Сафронова И.Н., Саксонов С.В., Сараева И.И., Сенатор С.А., Трошкина В.И., Васюков В.М., Ванг В., Сианг К., Зибзеев Е.Г., Золотов А.В., Зыкова Е.Ю., Кривенко А.А. Находки во фморе России и сопредельных стран: новые национальные и региональные мокалитеты сосудистых растений, 2. Впервые Аля России приводятся Ageratum conyzoides, Salvia bispanica, Thymus rasitatus, Tulipa mongolica, А^я Северной Кореи - Sparganium glomeratum, А^я Грузии - Alyssum armenum, А^я Казахстана - Thymus pseudopannonicus, А^я Азиатской части России - Cymbalaria muralis, Амя Сибири - Anthemis ruthenica, А^я Восточной Сибири - Capsella orientalis, Echinops sphaerocephalus, Heracleum sosnowskyi, Thymus elegans, Аля Западной Сибири - Persicaria orientalis, Аля Центрального Черноземья - Galatella crinitoides, Аля Заволжья - Centaurea orientalis, Аля Республики А^тай - Silene dichotoma, Аля Респуб̆лики Аагестан - Onobrychis arenaria, Symphyotrichum squamatum, Verbesina encelioides - Аля Республики Саха (Якутия) - Geranium daburicum, Аля Респуб̆лики Татарстан - Koeleria spryginii, Аля Сахалина - Phacelia tanacetifolia, Adonis wolgensis - Аля Новосибирской области. Аیя кажАого вила прелстав ены свеления об общем распространении, занимаемых местообитаниях, таксономии с указанием отличий от близких видов и местонахожАения. Мы приглашаем авторов участвовать в Аальнейшем развитии этого раздела. Пожалуйста присылайте материалы ответственному редактору раздела А^ле Васильевне Верхозиной (allaverh@list.ru).

Ключевые слова: флористические находки, таксономия, Россия, Казахстан, Грузия, Северная Корея, Кавказ
With this paper we continue a new annual series, the main purpose of which is to make significant floristic findings from Russia and neighboring countries more visible in Russia and abroad. This paper was prepared by the team united more by scientific cooperation than the taxonomy or geography of the species. In total, this paper 


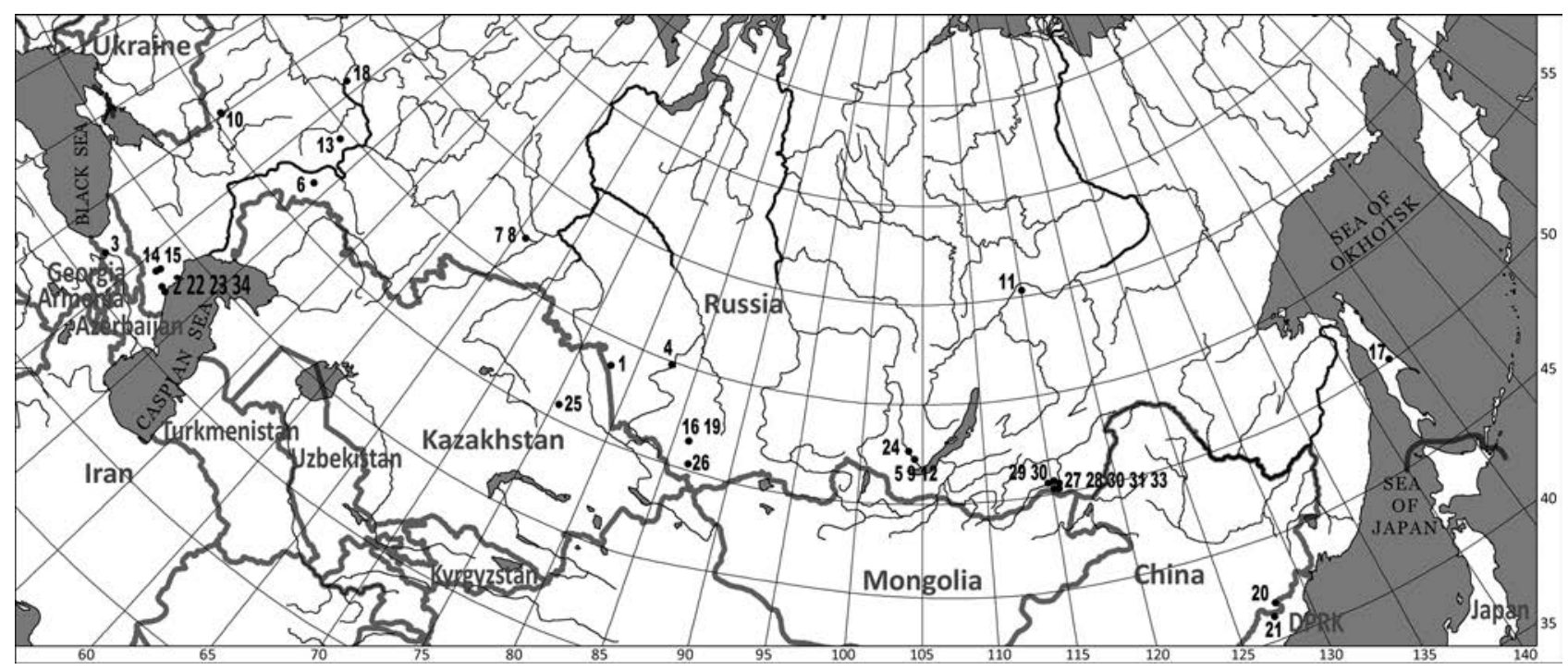

Figure 1 Locations of new findings: 1 - Adonis wolgensis Steven ex DC., 2 - Ageratum conyzoides L., 3 - Alyssum armenum Boiss., 4 - Anthemis ruthenica Bieb., 5 - Capsella orientalis Klokov, 6 - Centaurea orientalis L., 7, 8 - Cymbalaria muralis P. Gaertn., B. Mey. \& Scherb., 9 - Echinops sphaerocephalus L., 10 - Galatella crinitoides Novopokr., 11 - Geranium daburicum DC., 12 - Heracleum sosnowskeyi Manden., 13 - Koeleria spryginii Tzvelev, 14, 15 - Onobrychis arenaria L., 16 - Persicaria orientalis (L.) Spach, 17 - Phacelia tanacetifolia Benth., 19 - Silene dichotoma Ehrh., 20, 21 - Sparganium glomeratum (Laest.) Beurl., 22, 23 - Symphyotrichum squamatum (Spreng.) G.L. Nesom, 24 - Thymus elegans Serg., 25 - Thymus pseudopannonicus Klokov, 26 - Thymus rasitatus Klokov, 27-33 - Tulipa mongolica Y.Z. Zhao, 34 - Verbesina encelioides (Cav.) Benth. et Hook f. ex A. Gray

presents new records for 18 vascular plant species from 3 Eurasian countries, obtained during field explorations, as well as during taxonomic revisions of herbarium materials.

\section{Adonis wolgensis Steven ex DC. (Ranunculaceae)}

Contributors: Andrey S. Erst, Dmitry V. Zolotov, Kunli Xiang \& Wei Wang

\section{Distribution and habitat}

A. wolgensis is native to the European part of Russia, middle Asia, West Siberia, Caucasus, Hungary and Turkey (Bobrov 1937). According GBIF database (2020) this species is distributed in Azerbaijan, Estonia, Iran, Kazakhstan, Moldova, Romania, Russian Federation (excluding Novosibirsk Region), Serbia and Ukraine. It grows on dry steppes, open spaces in the forest. Adonis wolgensis has the earliest flowering stage in comparison to others sympatric species. This species prefers more dry places and south slopes.

\section{Taxonomic notes}

A. wolgensis differs from $A$. vernalis by pubescence leaves, straight and slanted to achene persistent stylus (vs. hooked). A. wolgensis is characterized by palmately dissected leaves, A. villosa has pinnately dissected leaves. Its flowers are paler and smaller in size than $A$. vernalis one's. Adonis villosa has smaller flowers in size than $A$. wolgensis.

\section{Examined specimens (new records)}

RUSSIA: Novosibirsk Region, Karasuk District, marsh Nadyr, steppe, $53^{\circ} 26^{\prime} \mathrm{N} 77^{\circ} 48^{\prime} \mathrm{E}, 100 \mathrm{~m}$ a.s.l., 16.06.1994 Shaulo D., Krasnikov A., Snytko O.) (NS): 1.

\section{Ageratum conyzoides L. (Asteraceae)}

Contributors: Maxim M. Mallaliev \& Ramazan A. Murtazaliev

\section{Distribution and habitat}

The North American species (grows south of the USA), currently widespread, mainly in countries with tropical and subtropical climates. It is cultivated as an ornamental plant, which contributes to its distribution outside the natural range. Previously, it was not given for the territory of the Russian Federation, but for the Western Transcaucasia (Sukhumi) it was indicated by Grossheim (1949). It usually grows in weedy places, along roads, along abandoned sites.

\section{Taxonomic notes}

From $A$. houstonianum Mill., which is widely cultivated, it differs by the obtusely or broadly cuneate leaves, as well as a pale (whitish) corolla. $A$. houstonianum has basally cordate or truncate leaves, corollas are blue..

\section{Examined specimens (new records)}

RUSSIA: Republic of Dagestan, in the coastal part of Kaspiysk city, on sandy soil with sparse vegetation, 20.10.2019, coll. M.M. Mallaliev (DAG, LE): 2.

\section{Alyssum armenum Boiss. (Brassicaceae)}

Contributor: Vladimir I. Dorofeyev \& Denis A. Krivenko Distribution and habitat

This species was previously known only to the northeastern part of Turkey. Busch (1939) mentioned it in the "Flora of USSR" in case it might be found in the SouthWest Transcaucasia. The find mentioned here from the Georgia extends the distribution of this species to the southwest to the Meskheti floristic region. Endemic to the northern part of Southwest Asia.

Mountainous dry slopes and rocky places, alt. 1200$3700 \mathrm{~m}$

\section{Taxonomic notes}

This species is the closest relative of $A$. daghestanicum Rupr. and $A$. muelleri Boiss. \& Buhse, but differs from other stellate hairs with a small number of rays that are located on the leaves.

\section{Examined specimens (new records)}

GEORGIA: Samtskhe-Javakheti Region, Akhaltsikhe Municipality, right bank of Kura River, on the way from Greli village to Sapara monastery, $1290 \mathrm{~m}$ a.s.l., 41 ${ }^{\circ} 36^{\prime} 54^{\prime \prime} \mathrm{N}$ $43^{\circ} 00^{\prime} 27^{\circ} \mathrm{E}, 23.07 .2019$, D.A. Krivenko \& al. 58210 (IRK), 58211 (LE), 58212 (VLA): 3. 


\section{Anthemis ruthenica Bieb. (Asteraceae)}

Contributor: Elena Yu. Zykova \& Aleksandr L. Ebel Distribution and habitat

A. ruthenica is native to Central and Eastern Europe, the Caucasus and the Balkan Peninsula (Greuter 2011). Within the natural range, this species grows on riverine sands, dry meadows, steppe slopes, in sparse forests and also in settlements (Tzvelev 1994). It is treated as dangerous invasive species in Europe, even in the Scandinavian countries (CABI 2020). For instance, $A$. ruthenica is abundant in eastern Germany in many cultivated fields (HYPPA 2020). It is also distributed as an alien species in Asia, namely in Kazakhstan, Kyrgyzstan, Uzbekistan and Turkmenistan (Kamelin \& Kovalevskaya 1993, Lazkov \& Sennikov 2014, Tojibaev et al. 2017). For Kyrgyzstan it is reported as an established alien plant naturalized in human-made and disturbed habitats at the regional scale (Lazkov \& Sennikov 2014).

In the European part of Russia, it has been observed since the beginning of the 20th century. It is currently quite common here in the southern regions, but north of the chernozem zone it is still very rare (Ignatov 2006, Mayorov et al. 2012). This species also was reported as casual alien for the Russian Far East (Barkalov 1992) where it was found on the railway in Vladivostok. A. ruthenica is recorded by us for the first time for Siberia.

\section{Taxonomic notes}

A. ruthenica is a representative of the genus, which includes ca. 160 species distributed in Europe, North and East Africa and West Asia, and as aliens in non-tropical and some tropical countries (Tzvelev 1994, POWO 2020). A. ruthenica is the third species of the genus in Siberia. Two other species are also alien here, these are widespread yellowflowered perennial plant $A$. tinctoria L. (三Cota tinctoria (L.) $\mathrm{J}$. Gay) and rare casual alien $A$. arvensis L. having white ray flowers. $A$. ruthenica is an annual or biennial with abundant friable pubescence, which makes the plant appear gray. It has stems branched from the base with pinnately divided oblong leaves and solitary corymbs on elongated thin peduncles; ray flowers white (Tzvelev 1994).

\section{Examined specimens (new record)}

RUSSIA: Novosibirsk Region, Novosibirsk City, Sovetskii microdistrict, Akademgorodok, Nikolaeva street, $54^{\circ} 59^{\prime} \mathrm{N} 83^{\circ} 00^{\prime} \mathrm{E}$, by the road, 02.06.2017, coll. E.Yu. Zykova. (NS, TK): 4.

\section{Capsella orientalis Klokov (Brassicaceae)}

\section{Contributor: Alla V. Verkhozina \& Aleksandr L. Ebel}

\section{Distribution and habitat}

For a long time, this species was considered endemic to Eastern Europe (Klokov 1926, Vasilchenko 1939, Dorofeev 2002), but now it is also known from the Altai Republic (Zolotukhin 1983), Altai Territory (Ebel 2002), and Chelyabinsk (Kulikov 2005), Kemerovo (Sheremetova et al. 2011), Novosibirsk and Tomsk Regions, the Republics of Khakassia, Tyva, as well as from Kazakhstan and the west of Mongolia (German \& Ebel 2009). Moreover, the main part of the natural range of the species is apparently located in the steppe zone of Kazakhstan. Probably, C. orientalis can also be found in Northwest China (German \& Ebel 2009).

Detailing the distribution of this species is somewhat difficult due to the difficulties of its identification (German \& Ebel 2009). We present only the location supported by the herbarium specimen in this publication. Although a number of unpublished, but uploaded to Plantarium and iNaturalist, locations from the Tyumen Region, Krasnoyarsk Territory and Irkutsk Region are known and identification of most of them seems reliable.

\section{Taxonomic notes}

The species is morphologically close to C. bursa-pastoris (L.) Medik., whose significant variability covers many parameters specific to $C$. orientalis.

Most clearly C. orientalis differs from C. bursa-pastoris in a living state especially when growing together. $C$. orientalis has two pale green (almost salad-colored) leaves and its flowers seem greenish or yellowish because the white color of the petals, slightly exceeding the sepals, is masked by the color of the sepals. Due to this, C. orientalis specimens contrast with the usually bright green plants of C. bursa-pastoris, whose petals are noticeably longer than the sepals, and the flowers always look bright white. In addition, the cauline leaves (at least part of them) in C. bursa-pastoris are usually bent arched, and in $C$. orientalis they are straight, upwardly directed. When plants are removed from the ground, the roots and basal leaves of $C$. bursa-pastoris emit a rather strong characteristic odor, while $C$. orientalis does not smell or smells weak. When identifying herbarium specimens, one of the main signs is the presence and depth of the notch on apex of the pod. C. orientalis pods have a notch of $0.7-1.2$ $\mathrm{mm}$, while in C. bursa-pastoris, the notch is absent or does not exceed $0.5 \mathrm{~mm}$. The column in $C$. orientalis on ripe pods does not exceed the notch, and in C. bursa-pastoris it exceeds. C. bursa-pastoris is commonly slightly pubescent with short trichomes or almost glabrous, wereas $C$. orientalis is usually quite densely pubescent with long simple trichomes (German \& Ebel 2009, Revushkin 2014).

\section{Examined specimens (new record)}

RUSSIA: Irkutsk Region, Irkutsk City, vicinity of Molodezhnyi village, experimental field of A.A. Ezhevsky Irkutsk State Agrarian University, weed on the field, $52^{\circ} 13^{\prime} 33^{\prime \prime} \mathrm{N}$, $104^{\circ} 25^{\prime} 06^{\prime \prime E}$, 12.07.2019, coll. A.V. Verkhozina, 58586 (IRK): 5.

\section{Centaurea orientalis L. (Asteraceae)}

Contributor: Vladimir M. Vasjukov, Anastasia V. Ivanova \& Irina N. Safronova

Distribution and habitat

C. orientalis (sect. Orientalis (Hayek) Tzvelev, subgenus Lopholoma (Cass.) Spach) described from the Don River of the European part of Russia: "In desertis ad Tanaim majorem circa nova Pawloska" [steppes along the Don River in the vicinity of Pavlovsk, Voronezh Region, Russia] Gerber s.n. in Herb. Linn. No. 1030.33 (Gerner 2010, Altinordu \& FerrerGallego 2016).

This species is common in southeastern Central and southern Eastern Europe and the Caucasus (Czerepanov 1994, LE!, MW!); first found in the left bank of the Volga (Saratov Zavolzhye). Grows in steppes, on dry rocky and sandy slopes.

\section{Taxonomic notes}

C. orientalis is a perennial plant up to $80-100 \mathrm{~cm}$ tall, covered with short papillary hairs, sometimes with an admixture of arachnoid felt, more or less rough, green; stems solitary or few, erect, usually with few lateral branches. Its leaves are pinnatipartite or pinnatipate, on rather long petioles; baskets are single or few at the top of the stem and lateral branches; wrappers are 15-24 mm wide and 17$25 \mathrm{~mm}$ long, bare; appendages are thin-skinned, yellowish, with a crest-ciliated margin; yellow flowers (Tzvelev 1963).

Other similar perennial species with yellow flowers from the subgenus Centaurea L., native to the Volga region (C. kasakorum Iljin, C. ruthenica Lam. and C. taliewii Kleopow) have bracts at the apex without appendages or appendages in the form of a membranous, entire border.

\section{Examined specimens (new records)}

RUSSIA: Saratov Region, Pugachev District, northern outskirts of the village of Bolshaya Tavolozhka, steppe 
slopes near the route Samara - Saratov, 21.06.2019, coll. A.V. Ivanova \& I.N. Safronova (PVB): 6.

\section{Cymbalaria muralis P. Gaertn., B. Mey. \& Scherb.} (Plantaginaceae)

\section{Contributors: Igor V. Kuzmin}

Distribution and habitat

C. muralis is a native to Southern Alps, Croatia, Bosnia and Herzegovina, Montenegro, Central and Southern Italy and Sicily (Webb 1972). It was introduced to Central Europe as an ornamental plant in the 16th century and since that time it reached North Europe, North Africa, East Asia, North and South America, Australia and New Zealand and was widely spread as cultivated and culture receding invasive plant (Szczęśniak \& Świerkosz 2003, Junghans \& Fischer 2008). In Russia there are records in Samara, Tver and Leningrad Regions, Moscow City and Saint-Petersburg City, on the Black Sea shores in Crimea and Caucasus (Ivanina 1981, Mayorov 2014). It grows on the walls of buildings and in foundation cracks. In Tyumen City C. muralis is a weed in the greenhouses. In 2009, during the repairing of a University's greenhouse, stones, road metal (crushed stone), pieces of concrete and construction waste were taken out. They were bulked in a long dump along the foundation. The C. muralis seeds fell between the stones and, as a result, the plants bloom and fructify annually in 2009-2020. From 5 to 40 individual plants appear every year. Successful colonization of this Mediterranean species to disturbed biotopes in severe Siberian climate is very interesting because winter temperature here goes down as low as $-40^{\circ} \mathrm{C}$. Probably, this plant is rescued by a thick snow cover formed in this place. In 2020 , a flowering plant of this species was discovered in another area of the city. The shoots covered an area of half a square meter. This species also came here with soil from the garden center, no doubt. But it is interesting that only shrubs and perennials grow on this place. Flower beds with annual ornamental plants are not here. The plant could also live here for several seasons. C. muralis is a new alien species to the flora of Siberia and for the entire Asiatic part of Russia.

\section{Taxonomical notes}

There are three subspecies of $C$. muralis according to the degree of pubescence of the plants (Webb 1972). Plants from Tyumen do not have hairs and belong to a typical subspecies $C$. muralis subsp. muralis.

\section{Examined specimens (new records)}

RUSSIA: Southern Trans-Urals, Tyumen Region, Tyumen City, 3 Pirogova Str., 56 $16^{\prime} 54.6^{\prime \prime} \mathrm{N}, 44^{\circ} 00^{\prime} 32.8^{\prime \prime} \mathrm{E}$, pieces of stones and road metal taken out from the greenhouse, JuneOctober 2009-2020, obs. I.V. Kuzmin every year (photos) and 31.08.2011 coll. I.V. Kuzmin s.n. (LE, MW, Tyumen State University); Tyumen Province, Tyumen city, 50B Permyakova Str., $57^{\circ} 07^{\prime} 07.9^{\prime \prime} \mathrm{N}, 65^{\circ} 34^{\prime} 41.1^{\prime \prime E}$, sidewalk between the "Solnechny" shopping center and Alexander Logunov St., a small garden with decorative coniferous shrubs and decorative stones, 03.09.2019 coll. I.V. Kuzmin s.n. (Tyumen State University): 7, 8.

\section{Echinops sphaerocephalus L. (Asteraceae)}

Contributors: Alla V. Verkhozina, Aleksandr L. Ebel, Nikolay V. Dorofeev \& V.V. Murashko

\section{Distribution and habitat}

E. sphaerocephalus is widespread across much of Eurasia and was introduced to other continents, including North America, where it is sometimes cultivated and escapes from cultivation, Africa and Australia (Keil 2006, GBIF 2019). In Siberia, this species is probably native only in Western Altai (Ebel 2017), but is known as an alien plant from the Kemerovo Region (Krasnoborov 2001), south of the Krasnoyarsk Territory (Cherepnin 1967), and the Republic of Khakassia (Ebel 2017). It was also recorded for Kurgan, Omsk and Tyumen Provinces (Zhirova 1997) without location and status (native or alien). However, locations in Kurgan and Tyumen Regions is non confirmed by herbaria materials (Naumenko 2008). On the other hand, the latter author indicated the ability of the species to self-sow outside plantings in Kurgan.

\section{Taxonomical notes}

E. sphaerocephalus differs from other Siberian Echinops L. species in larger sizes up to $1.5-2.0 \mathrm{~m}$ in height in combination with white or blue-gray pseudocephalia and white to pale blue corolla. E. sphaerocephalus is one of two species of the section Echinops grown in Siberia. The second species, E. latifolius Tausch, has a blue pseudocephalia and corolla. The outer involucral bracts of E. sphaerocephalus is glandular, E. latifolius is not glandular.

\section{Examined specimens (new record)}

RUSSIA: Irkutsk Region, Irkutsk City, vicinity of Pivovarikha village, wasteland, and by the road for $700 \mathrm{~m}$, $52^{\circ} 16^{\prime} 38^{\prime \prime} \mathrm{N}, 104^{\circ} 26^{\prime} 25^{\prime \prime} \mathrm{E}, 12.07 .2019$, coll. A.V. Verkhozina \& N.V. Dorofeev, 58587-58591 (IRK): 9.

\section{Galatella crinitoides Novopokr. (Asteraceae)}

Contributor: Vladimir M. Vasjukov, Stepan A. Senator \& Anna Ya. Grigorjevskaja

\section{Distribution and habitat}

G. crinitoides was described from Karkaralinsk (Kazakhstan). This taxon is quite rare common in the South-East of the European part of Russia (Middle and Lower Volga, Southern Urals), the South of Western Siberia and the North of Kazakhstan (Tzvelev 1959, 1994, LE!, MW!, PVB!), and was not known from the South of Central Russia. It grows on steppe slopes, limestone and chalk outcrops.

\section{Taxonomic notes}

$G$. crinitoides is a hybridogenic species that comes from hybridization $G$. angustissima (Tausch) Novopokr. $\times$ G. villosa (L.) Rchb.f.

G. crinitoides is grayish from fairly abundant pubescence perennial plant $15-40 \mathrm{~cm}$ high with upright leafy stems and alternate oblong-linear entire leaves $2.5-4 \mathrm{~mm}$ wide; heads with 10-20 flowers, among which there are usually 2-5 poorly developed pale blue lingular flowers.

Distinctive features of genitive species: G. angustissima is glabrous or almost glabrous plant, baskets always have 5-10 (15) blue or blue-violet lingular flowers, leaves narrowly linear 1-2 $\mathrm{mm}$ wide (except early dying off lower linearlanceolate leaves); G. villosa is grayish-felt plant, with heads without lingular flowers and the oblong-linear or oblong leaves (3)4-10 mm wide.

$G$. crinitoides is habitually similar to $G$. tatarica (Less.) Novopokr., which is almost a glabrous plant (it has a very thin felt that disappears by the beginning of flowering) with heads containing 5-8 (10) tubular flowers (lingular flowers are absent).

\section{Examined specimens (new records)}

RUSSIA: Voronezh Region, Podgorenskiy District, vicinity of Kirpichi Khutor, Belogor'e stow, chalk slope, 21.06.2009, coll. O.V. Prokhorova (VORG): 10.

\section{Geranium daburicum DC. (Geraniaceae)}

\section{Contributor: Victoria I. Troshkina}

\section{Distribution and habitat}

G. daburicum has a Mongol-Daurian distribution. It occurs in the forest margins, meadows and steppes (Peshkova 1996, Tsyrenova 2007). A new location of $G$. daburicum was discovered during work on the Herbarium of Komarov Botanical Institute RAS (LE). It is a new species for the Republic of Sakha (Yakutia). 


\section{Taxonomic notes}

G. daburicum is a perennial plant. Rhizome short about $1 \mathrm{~cm}$ long with spindle-shaped thickened roots $4.5-5 \mathrm{~cm}$ long. The stems are 15-20 (30) cm tall, single, erect, thin, branched forked forks at the top. The stems are covered with short down deflected trichomes. Basal leaves most often perish by the flowering time. Stem leaves are opposite petiolate. Leaf blades almost to the base dissected into 5-7 narrow lobes. Stipules loose, sometimes fused, membranous, brown. Peduncles solitary, axillary, 2-flowered, with fruits almost do not elongate and deviate laterally. Pedicels elongate at fruiting and arcuate deflected downwards. Flowers $1-1.5 \mathrm{~cm}$ in diameter. Sepals 1.5 times shorter than the petals, with 3 veins, acuminate at apex. Petals are pale-lilac or pinkish, rarely white, the veins are darker colored, pubescent with weak matted hairs from below. Anther filaments are gradually narrowed, short ciliated along margin. The leaves of the fruit are smooth with small pressed simple and longer glandular trichomes.

Bobrov (1949) referred $G$. daburicum to the section Sanguinea Knuth. Novosselova (1999) considered the species as part of the section Palustria Knuth. D.Yu. Tsyrenova (2007) based on a number of features distinguishes the species into an independent section of Daburica Tzyren. $G$. daburicum characterized by long, uniformly thickened roots, one circle of conducting bundles in the internodes.

\section{Examined specimens (new records)}

RUSSIA: The Republic of Sakha (Yakutia), Lensky District, forest corridor for a telephone line on the left bank of the Lena River to the Murya village, $11 \mathrm{~km}$ from the Mukhtuya village [Lensk], among shrubs, No. 18/1, 5.07.1953, V.B. Kuvaev (LE): 11.

\section{Heracleum sosnowskyi Manden. (Apiaceae)}

Contributors: Alla V. Verkhozina, Aleksandr L. Ebel \& Nikolay V. Dorofeev

\section{Distribution and habitat}

H. sosnowskyi is native to the Central and Eastern Caucasus, Transcaucasia, and northeast of Turkey. Its secondary range includes the countries of the Baltic Region (Denmark, Poland, Estonia, Lithuania, Latvia), Belarus, Ukraine, Russia. H. sosnowskyi had been cultivated for biomass and silage production in the former USSR in the second half of the twentieth century. Since 1948 there are first reports on the plant escaping from cultivation and since 1970 s the process has become expended (Vinogradova et al. 2010). To date, the species is widely spread in the European part of Russia. It is also found in the Urals, the south of Western Siberia and the Far East (Zykova 2016, Vinogradova et al. 2020).

In Siberia, trials of the species as a silage plant began in the 1960s (Sokolov et al. 1965). The first findings of H. sosnowskyi outside agrocenoses were recorded in the Altai Territory and the Altai Republic in 2005 (Silantieva et al. 2005), where it continues to spread (Shaulo \& Zykova 2013, Zykova 2015). H. sosnowskyi was also found in the Kurgan (Naumenko 2008), Tyumen (Kuzmin 2008), Novosibirsk (Shaulo \& Zykova 2013) and Tomsk Regions (Ebel et al. 2018). Additionally, data on the findings of this species in the Kemerovo Region and in the environs of Krasnoyarsk (Dalke et al. 2020) are available, but we are not sure what their reliability concerns (Ebel et al. 2018).

\section{Taxonomic notes}

Together with $H$. mantegazianum Sommier \& Levier and some other species of this genus, H. sosnowskyi is a part of the group of so-called "giant hogweed" (taxonomically, representatives of the section Pubescentia Manden.), named for stem height (usually more than $2 \mathrm{~m}$ ) and large leaves (Nielsen et al. 2005). It should be noted that neither in the protologue nor in the description in "Flora of the USSR"
(Mandenova 1944, 1951) there are no indications of its gigantism. There are still many ambiguities in the taxonomy of species of the genus Heracleum (including the group "giant hogweed"), and different authors do not equally understand both the volume of species and their ranges (Jahodová 2007, Pimenov \& Ostroumova 2012). Obviously, the using of the name $H$. sosnowskyi for introduced and wild "giant hogweed" is quite conditional.

The ability of hogweed to interspecific hybridization is well known, which makes the identification of species complicated (Kabuce \& Priede 2010). Probably the information on the locations of $H$. sosnowskyi in the Asian part of Russia is partly related to other species of giant hogweed, in particular, to $H$. mantegazzianum. In Siberia, the hybridization of the invasive species $H$. sosnowskyi and native species $H$. dissectum Ledeb. and $H$. sibiricum L. is also possible.

Three species of giant hogweed $H$. sosnowskyi, $H$. lehmannianum Bunge and $H$. pubescens (Hoffm.) M. Bieb. were tested in the same trial in the experimental fields of the Irkutsk State Agrarian University in 1974-1976. The cultivation of $H$. pubescens was most successful and the percentage of plant survival over winter was about $67 \%$. H. sosnowskyi and $H$. lebmannianum shawed low winterhardiness in the environmental conditions of the Irkutsk Region. The percentage of plant survival over winter of 1974-1975 was 3-5\% (Terskikh 1977), but according to our data, the trials of giant hogweeds were continued and completely stopped only in the late 1980s.

The close species $H$. mantegazzianum is distinguished by protruding pubescent rays of umbels and secondary umbels and acute leaf lobes (Mandenova 1951), while H. sosnowskyi has only short hairs of umbels and secondary umbels and obtuse leaf lobe. Our specimens have short pubescence, relatively acute leaf lobes, and significantly larger mericarps than indicated for $H$. sosnowskyi.

\section{Examined specimens (new records)}

RUSSIA: Irkutsk Region, Irkutsk City, vicinity of Molodezhnyi village, edge of a birch forest, $052^{\circ} 13^{\prime} 33.76^{\prime \prime} \mathrm{N}$ $104^{\circ} 25^{\prime} 27.57^{\prime \prime E}, 12.07 .2019$, coll. A.V. Verkhozina \& N.V. Dorofeev, 58592-58595 (IRK), 18.08.2019, coll. A.V. Verkhozina, N.V. Dorofeev, 58596-58599 (IRK): 12.

\section{Koeleria spryginii Tzvelev (Poaceae)}

Contributor: Vladimir M. Vasjukov, Stepan A. Senator, Sergey V. Saksonov, Andrey Yu. Korolyuk \& Evgenii G. Zibzeev

\section{Distribution and habitat}

K. spryginii is endemic of European Russia, which has been described from the Republic of Mordovia, vicinity of Novaya Uda village (Tzvelev 2010). The main area of this species is located in the Middle Volga River Basin: Republic of Mordovia (East), Nizhnij Novgorod (South), Penza (North), Orenburg (North-West), Samara (pre-Volga areas and Vysokoe Zavolzh'e), Saratov (pre-Volga areas), and Ul'yanovsk (northern and pre-Volga areas) Regions (LE!, MW!, PKM!, PVB!). In 2019, the species was first found in the Republic of Tatarstan. It grows on chalk, marl and cretaceous outcrops.

\section{Taxonomic notes}

K. spryginii is the result of introgressive hybridization K. sclerophylla P.A. Smirn. $\times$ K. cristata (L.) Pers. (Tzvelev 2010).

It is densely or loosely caespitose plant $25-60 \mathrm{~cm}$ tall. The stems under the panicle are $1-2.5 \mathrm{~cm}$ pubescent. The sheaths of the lower stem leaves are short-pubecence or almost glabrous; the leaf blades $0.4-1.5 \mathrm{~mm}$ wide, they are rolled along often, rigid, gray-green, scabrous on top, sparsely pilose or partly glabrous on bottom. The panicles $3-8 \mathrm{~cm}$ long, rather loose. The spikelets $3.7-5 \mathrm{~mm}$ long, glabrous. 


\section{Examined specimens (new records)}

RUSSIA: Republic of Tatarstan, Drozhzhanovsky District, south-eastern vicinity of Novoe Chekurskoe village, natural monument 'Novo-Chekurskaya lesostep' (Keremet')", stony steppe, 09.06.2019, coll. V.M. Vasjukov, S.A Senator, A.Yu. Korolyuk \& E.G. Zibzeev (MW, PVB): 13.

\section{Onobrychis arenaria L. (Fabaceae)}

Contributors: Ramazan A. Murtazaliev \&

Ziyarat A. Guseinova

\section{Distribution and habitat}

It occurs from Central Europe to Mongolia and Northwest China (Jakovlev 1996, Menitsky 2001). In the North Caucasus, the species grows in lowlands and lower foothills along steppe and sandy places, as well as in shrubs and dry meadows (Grossheim 1952). The species is first recorded for the flora of Dagestan. The specimens of this species were stored in the herbarium of the Dagestan University (LENUD). They were collected in the middle of the 20th century during the certification of pastures of Dagestan under the direction of E.V. Schiffers and were identified by L.N. Chilikina as O. tanaitica Spreng. The nearest location of the species is in the vicinity of the Herzel village (Chechen Republic), which at that time was part of Dagestan.

\section{Taxonomic notes}

$O$. arenaria is a very polymorphic species, which in different parts of the area was considered as different species. So, in the "Flora of the USSR" (Grossheim 1948), 4 species were distinguished $(O$. arenaria, $O$. tanaitica, $O$. sibirica Turcz. ex Besser and O. ferganica Sirj.) Grossh.)) which are now considered synonyms of the type subspecies $O$. arenaria subsp. arenaria.

\section{Examined specimens (new records)}

RUSSIA: Republic of Dagestan, Khasavyurtovsky District], between shrubs in $3 \mathrm{~km}$ south of Khasavyurt, 05.06.1951, coll. Mikhailov (LENUD); Republic of Dagestan, Shuragatsky district, in the thickets of Paliurus spina-chris$t i$, on the way from Gerzel village to the Alleroi village, 22.05. 1955, coll. L.N. Chilikina \& N. Yarulina (LENUD): 14, 15.

\section{Persicaria orientalis (L.) Spach (Polygonaceae)}

\section{Contributor: Aleksandr L. Ebel \& Elena Yu. Zykova}

\section{Distribution and habitat}

P. orientalis is native to SE Asia and mostly northern Australia, where it grows on riverine sands and pebbles, as well as in disturbed habitats (Tzvelev 1996, Mayorov et al. 2012). It is often cultivated in Europe as an ornamental plant, and as alien plant is found in many countries in populated areas and along roadsides. In the European part of Russia, several locations of this species outside of culture were recorded in the Moscow, Kursk and Voronezh Provinces (Mayorov et al. 2012, Poluyanov \& Sklyar 2015). In Siberia, it was recently noted as alien plant in Irkutsk (Verkhozina et al. 2019).

\section{Taxonomical notes}

P. orientalis (三 Polygonum orientale L., Amblygonum orientale (L.) Nakai ex T. Mori) is a representative of the genus numbering about 150 species distributed in moderately warm and tropical regions of the northern hemisphere, as well as in South America (Tzvelev 1996). About 10 species of the genus are known in Siberia (Baikov 2012). P. orientalis belongs to the section Amblygonon (Meisn.) Tzvelev (Tzvelev 1989), which contain 2 species ( $P$. orientalis and P. pilosa (Roxb.) Kitag.). This is a tall annual (up to $2 \mathrm{~m}$ ) with large bright crimson-pink spike-shaped inflorescences. Both species of this section are characterized by stems and peduncles densely covered with simple hairs, tubular ocreas with usually green leaflike bent out wing, as well as two stigmas in flowers.
However, $P$. orientalis usually have less abundant downiness of stem and leaf (with more pressed trichomes) than P. pilosa.

\section{Examined specimens (new record)}

RUSSIA: Altay Republic, Gorno-Altaisk City, Protichnaya str., $51^{\circ} 58^{\prime} \mathrm{N} 85^{\circ} 55^{\prime} \mathrm{E}$, wasteland, 18.08.2017, coll. E.Y. Zykova (NS, TK): 16.

\section{Phacelia tanacetifolia Benth. (Boraginaceae) \\ Contributors: Kirill A. Korznikov \& Ksenia B. Popova \\ Distribution and habitat}

The native distribution of $P$. tanacetifolia includes the Southwestern United States (Arizona, California, Nevada) and Northwest Mexico (Baja California) at sandy to gravelly slopes and open areas (Wiggins 1980, Hickman 1993). It was introduced in several regions of USA and Canada, Europe, Central Asia (Kazakhstan, Kyrgyzstan, Tajikistan, Uzbekistan), Australia and New Zealand (Hassler 2020). In Russia P. tanacetifolia occurs in the European part of the country, Caucasus, Ural, Southern Siberia (Gorshkova 1953). In the Russian Far East this species was recorded in the Amur River basin, Primorsky Region (Kozhevnikov \& Kozhevnikova 2007), and Central Kamchatka (Ueda 2020). $P$. tanacetifolia is cultivated for a honey production, soil improvement or for ornamental purposes. It is considered as a naturalized or invasive species. We recorded this species at the post-mining area on a rock dump surface, in the upper part of the Langeri River, central part of Sakhalin Island. The propagules of $P$. tanacetifolia were carried there accidentally with a seed grass mixture for vegetation restoration.

\section{Taxonomic notes}

Phacelia Juss. (Hydrophylloideae) is the largest genus in Boraginaceae family. It includes about 200 species which are mostly distributed in the western parts of North and South America. The center of species diversity is California where 93 taxa occur, 39 are endemic among them (Gilbert et al. 2005). Phacelia contains three subgenera: Phacelia (with 8 sections), Microgenetes (A. DC.) A. Gray (with 3 sections), and Pulchellae (Rydb.) Waiden \& R. Patt (the number of sections is not determined so far). P. tanacetifolia and the other 30 taxa belongs to subgenus Phacelia, section Ramosissimae (Rydb.) Waiden \& R. Patt. (Walden \& Patterson 2012).

\section{Examined specimens(new records)}

RUSSIA: Sakhalin Region, Sakhalin Island, Smirnikhovsky District, Langeri River upper stream, $50^{\circ} 05^{\prime} 50^{\prime \prime} \mathrm{N}$ $143^{\circ} 18^{\prime} 42^{\prime \prime E}, 280 \mathrm{~m}$ a.s.l., post-mining landscape, rock dump surface, 18.08.2018, coll. K.B. Popova \& K.A. Korznikov 82688, 82687, 82686 (VBGI): 17.

\section{Silene dichotoma Ehrh. (Caryophyllaceae) \\ Contributors: Aleksandr L. Ebel \& Elena Yu. Zykova \\ Distribution and habitat}

This species is native to Eastern and South Europe and Western Asia, and as alien plant it can also be found in West and North Europe, North Africa, Kazakhstan, Japan, North America, New Zealand and Australia (Hulten \& Fries 1986, Morton 2005, Marhold 2011, Kupriyanov et al. 2015, GBIF 2019). In the secondary area it is found in crops, on deposits, near roads and housing. The species belongs to the number of common weeds that clog crops of cereals, clover, lecerne and other crops. The first in Siberia location was discovered near the city of Tobolsk (Krylov 1931). To date, the species has been recorded in the Omsk Region (Zuev 1993), Altai Territory (Silantieva et al. 2003), Tyumen and Kurgan Regions (Naumenko 2008), Kemerovo Region (Ebel 2013), and the Republic of Khakassia (Ebel et al. 2017). For the Republic of Altai this species is recorded for the first time. 


\section{Taxonomic notes}

Annual or biennial with stout puberulent to hispid erect stems up to $1 \mathrm{~m}$ high, branched dichotomously (usually 2-branched) at the summit; leaves spathulate to lanceolate, the lower with long petioles; cauline leaves lanceolate, whitevillous with long septate hairs. Flowers almost stalkless, (half-)nodding in same direction, fragrant. Inflorescence a quite abundantly-flowered raceme. Calyx up to $15 \mathrm{~mm}$ long., with sharp teeth approx. $3 \mathrm{~mm}$, covered with harsh hairs. Petals 1.5 times longer than the sepals, white, bifid, with a small crow (Gubanov et al. 2003, Morton 2005). It differs well from other Siberian species of Silene L. in a deeply forked inflorescence with almost sessile (stalkless) flowers, pubescence of the calyx with long harsh hairs, as well as a short life cycle (annual or biennial).

\section{Examined specimens (new records)}

RUSSIA: Altay Republic, Gorno-Altaisk City, "Rodnik" bus stop, $51^{\circ} 58^{\prime} \mathrm{N}, 85^{\circ} 55^{\prime} \mathrm{E}$, Maima riverbank, 15.07.2019, coll. E.Yu. Zykova (NS, TK): 19.

\section{Sparganium glomeratum (Laest.) Beurl. (Typhaceae)}

\section{Contributor: Alexey V. Grebenjuk}

\section{Distribution and habitat}

S. glomeratum is a cool-temperate circumboreal species widely (but disjunctively and sporadically) distributed in extra-tropical Eurasia: from Scandinavia and north Europe to Tibet and Kamchatka. S. glomeratum essentially grows in shallow mesotrophic neutral water of pools, small ponds, temporary streams and ditches that have varying water levels and can occasionally dry out. This species has only terrestrial form and occurs in swamp deciduous forests (on wet meadows covered by sedges $S$. glomeratum is often collected with $S$. natans L.), herbaceous margins of swamps, bogs, lakes and slow-moving rivers (Ohwi 1965, Cook \& Nicholls 1986, Tzvelev 1996, Kaul 2000, Kun \& Simpson 2010).

In Asian Pacific Region this species was documented by many reports for the Russian Far East, Japan, all of the three provinces of Northeast China (Heilongjiang, Jilin, Liaoning), Nei Mongol and Yunnan (Cook \& Nicholls 1986, Tzvelev 1996, Kun \& Simpson 2010). However, until very recently, $S$. glomeratum was not registered to inhabit the Korean Peninsula and the Korea in general (Anonym. Flora Coreana 1976, T.B. Lee 1980, Y.N. Lee 1996, Kim \& Choi 2007, Kun \& Simpson et al. 2010). This species was provisionally indicated by C.D.K. Cook \& M.S. Nicholls (1986) for North Korea, but no herbarium material on $S$. glomeratum was known for a long time. Although some information on the oldest reliable specimen of the $S$. glomeratum from North Korea was mentioned in a short report (Grebenjuk 2012: 1412, in adnot.), the very recent first record of this species for South Korea (Gangwon-do Province) also claimed to be the first record for the Korea in general (Gil et al. 2019) and the previous note from North Korea was neglected. In most recent checklists of the Korea (C.-S. Chang et al. 2014, K.S. Chang et al. 2017) this species is absent.

In 2018, in addition to the V.L. Komarov's herbarium specimen originated from the Korean bank of the Yalu River, the specimen stored under the name Sparganium sp. at the Herbarium of the Komarov Botanical Institute RAS (LE) was identified by the author of this report as $S$. glomeratum. Thus, in addition to South Korea, the distribution of $S$. glomeratum is confirmed for North Korea.

\section{Taxonomic notes}

S. glomeratum was described from the vicinities of Hernösand, Sweden ("Vid Hernösand anmärktes denna varieté àr 1843 $i$ kall-källdrag"). Lectotype is designated by C.D.K. Cook \& M.S. Nicholls (1986: 242): herb. № S-G-5719 "S. simplex $\gamma$. glomeratum Laest. Hernösand 1843” (S). S. glomeratum differs from similar species with nonbranched inflorescense $S$. japonicum Rothert, S. fallax Graebn. and $S$ emersum Rehm. by less number of male heads (2-3(4)), near absence of gap between male and female heads with fast-drying axis in male part, the small anthers (0.6-0.8 $\mathrm{mm}$ long), and the shortest among morphologically similar species in the group stigmas $(0.4$ $0.6 \mathrm{~mm}$ long). The species is rather constant in taxonomic characters throughout its range (Cook \& Nicholls 1986, Tzvelev 1996, Kaul 2000, Kun \& Simpson 2010, etc.). On the territory of Transbaikal Siberia, South Yakutia, and in Japan plants with more narrow leaves are often found, but these specimens known as $S$. glomeratum var. angustifolium Graebn. [1900, in Engl., Pflanzenr. IV, 10: 20] are not variable in characters of inflorescences, morphology of male or female heads. Larger and more vigorous specimens with more numerous female heads and occasionally with branched inflorescences from Sakhalin Island, South Kuril Islands, South Primorye (Russia), Japan and Heilongjiang (China), which were described as S. glehnii Meinsh. [1893, Bull. Acad. Imp. Sci. Petersb., N.S. 4, 36: 34] and S. manshuricum D.Yu [1992, Bull. Bot. Res., Harbin 12: 255], probably represents a local variants of $S$. glomeratum rather than distinct taxa. This species is not a true water form.

It is important to note that the traditional use of the name $S$. glomeratum is in conflict with the priority of $S$. fluitans (Fr.) Fr. Moreover, the legitimacy of the name $S$. glomeratum is doubtful, since in its publishing, both at the rank of the species and the variety, the nomenclatural type of $S$. fluitans was not clearly excluded. The taxonomic meaning of $S$. fluitans is also ambiguous. It was first published at the rank of variety with a brief diagnosis (Fries 1817: $139-$ "pusillum, foliis decumbentibus natantibus, sequentis multo latioribus \& brevioribus, basi 3 -quetris") which assumes its broad interpretation. No original material of $S$. simplex $\beta$ fluitans Fr. was found (Cook \& Nicholls 1986). However, when publishing the name S. fuitans, E.M. Fries (1849: 559) cited a direct and complete reference to $S$. simplex $\beta$ fluitans $F$ r. (hence adopted the name of the variety as the basionym for combination) and presented a new detailed description, from which it is clear that the taxon now known as $S$. glomeratum was meant. Cook \& Nicholls (1986) considered the name $S$. fluitans semantically unsuitable and recommended the use of $S$. glomeratum in future. Though, according to the current ICN (Turland et al. 2018), the formal procedure of conservation/rejection of the names has not yet been carried out.

\section{Examined specimens (new records)}

NORTH KOREA (DPRK): Hab. Korea, Mount Paektusan, Samjiyon [Ryanggang-do Province], 20.07.1958, coll. Sang Tok U. № 218 (LE01044013); Flumen Amnok-gan, Korea Septentrionalis, Provincia Pen-nian, distr. Samsu, [near village Sang-su-u], 4 VII 1897, coll. V.L. Komarov, s.n. (LE01001037): 20, 21.

\section{Symphyotrichum squamatum (Spreng.) G.L. Nesom (Asteraceae)}

Contributors: Ramazan A. Murtazaliev \& Maxim M. Mallaliev

\section{Distribution and habitat}

The natural range of the species covers South America. In Europe and in other countries it is an alien species and is now found almost everywhere. In 2019, the species is given for Crimea (Ryff 2019). In the Caucasus, the species was indicated (Tamamshyan 1959) for the countries of the Transcaucasus (Azerbaijan, Georgia). For the Russian part, it was not given (Tzvelev 2008), but in recent years it has been collected from the Western Transcaucasia: Krasnodar Territory, Sochi, under the trees in the park, 28.08.2008, G. Konechnaya (LE). It grows in weedy places, along roads, in parks and in other ruderal places. 


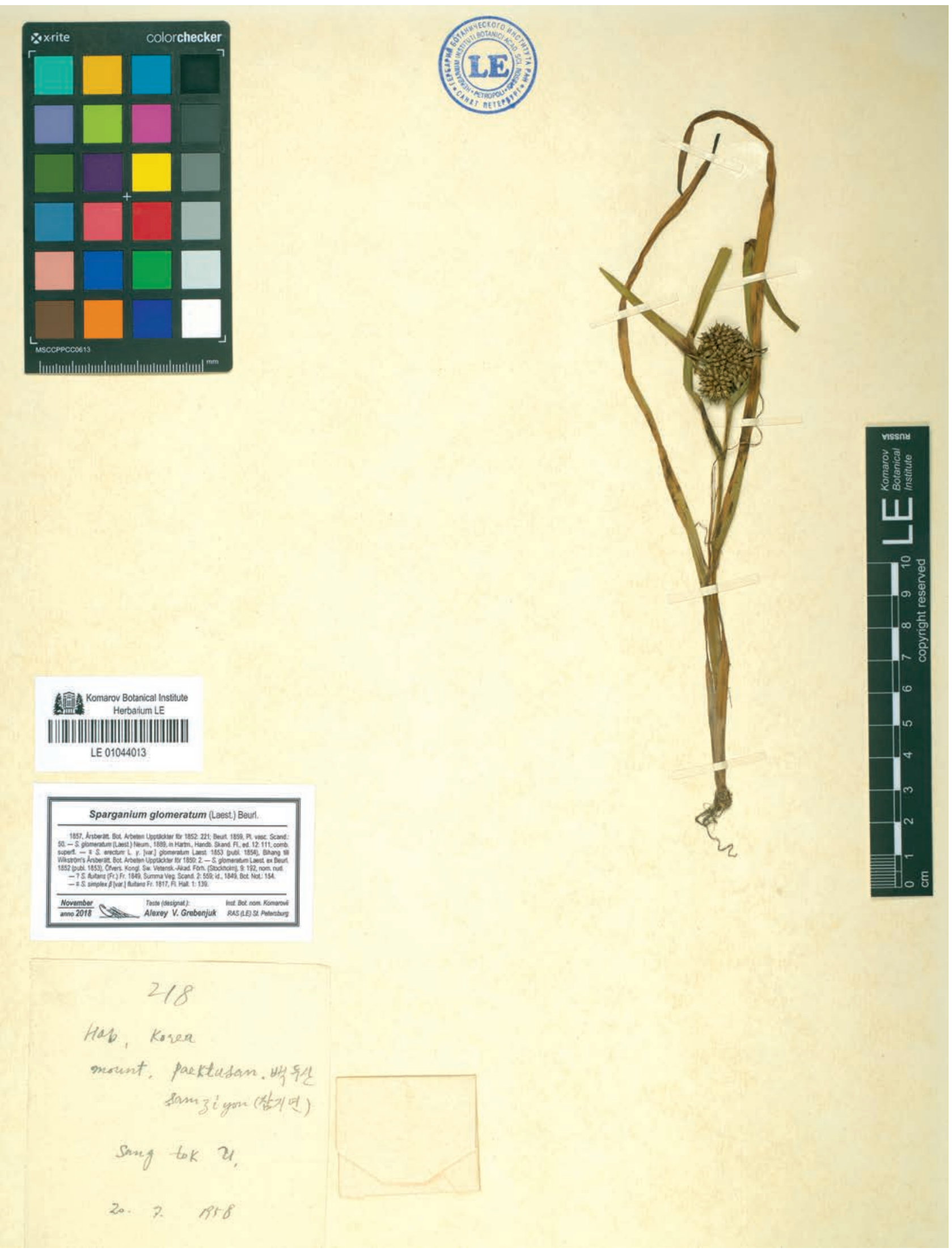

Figure 2 A specimen of Sparganium glomeratum (Laest.) Beurl. from North Korea collected near mt. Paektusan (LE01044013) 


\section{Taxonomic notes}

According to Ryff (2019), the species was mistaken for S. graminifolium (Spreng.) G.L. Nesom due to imperfect diagnostic key in the Flora of USSR (Tamamshyan 1959).

\section{Examined specimens (new records)}

RUSSIA: Republic of Dagestan, Kaspiysk city, along the road on the outskirts of the city, 6.08.2019, coll. M.M. Mallaliev (DAG, LE); Republic of Dagestan, Makhachkala City, ter. of the Dagestan Federal Research Center of the RAS (M. Yaragskogo Str. 75), 18.08.2019, coll. R.A. Murtazaliev (DAG, LE): 22, 23.

\section{Thymus elegans Serg. (Lamiaceae)}

Contributors: Vladimir M. Vasjukov \& Denis A. Krivenko Distribution and habitat

Th. elegans was described from the Russian Altai, neighborhood of Chemal village (Sergievskaya 1956). Previously, this species is known in the southeast of Western Siberia and the south of Middle Siberia (Doronkin 1997), but in the south of Eastern Siberia it was not known. It grows on steppe slopes.

\section{Taxonomic notes}

Th. elegans belongs to the section Serpyllum (Mill.) Benth. It differs from a close endemic Altai species Th. asiaticus Serg., belongs to the same section, by strongly separated internodes, spaced inflorescences, green calyces, and more high generative shoots.

\section{Examined specimens (new records)}

RUSSIA: Irkutsk Region, Angarsk City, left bank of Kitoi River, $455 \mathrm{~m}$ a.s.l., 52 $33^{\prime} 13^{\prime \prime} \mathrm{N}, 103^{\circ} 51^{\prime} 46^{\prime \prime E}$, sandy riverbank, 16.07.2018, coll. D.A. Krivenko \& al. 50781 (IRK), s.n. (PVB): 24.

\section{Thymus pseudopannonicus Klokov (Lamiaceae)}

Contributors: Vladimir M. Vasjukov \& Denis A. Krivenko Distribution and habitat

Th. pseudopannonicus was described from the Southern Urals: Bashkiria, Irendyk ridge, Ulugur-Tau mountains (Klokov 1973). The species is distributed in European Russia: High Transvolga, Southern Urals, and Central Russian Upland (Klokov 1973, MW!, PVB!, SVER!). Th. pseudopannonicus was not previously found in Kazakhstan. It grows on stony steppes.

\section{Taxonomic notes}

Th. pseudopannonicus has shortened or short ligneous stems (boles), ending in ascending generative shoots. Vegetative (5-10 cm long) and generative (5-15 cm long) shoots almost to the base are densely pubescent with protruding hairs. Leaves sessile, oblong-elliptic, 8-17 mm long, 1.5$6 \mathrm{~mm}$ wide, on both sides rather densely pubescent with protruding long hairs. Inflorescences $1.5-6 \mathrm{~cm}$ long, interrupted with 2-4 spaced false whorls, calyces during flowering 2.5-3.5 mm long, during fruiting sometimes up to $4 \mathrm{~mm}$ long, corollas about $4 \mathrm{~mm}$ long, pink-lilac, pale.

Th. pseudopannonicus belongs to the independent race of the section Verticillati Klokov, series Marschalliani Klokov \& Des.-Shost. and does not detect noticeable fluctuations in its morphological characters. It is always clear differs from Th. marschallianus Willd. even when they grow together. In taxonomic biodiversity databases such as "Euro+Med" (2006-), "The Plant List" (2013), "POWO" (2019), "WCVP" (2020), East European-West Asian Th. marschallianus и Th. pseudopannonicus, as well as Th. stepposus Klokov \& Des.-Shost., unreasonably considered as synonyms of the Central European Th. pannonicus All. (三 Th. pulegioides L. subsp. pannonicus (All.) Kerguélen). All species listed here are not conspecific, and, in our opinion, their association under the name of Th. pannonicus is mistakenly.

\section{Examined specimens (new records)}

KAZAKHSTAN: Pavlodar Region, Bayanaulsky District, Bayanaul National Park, near of Birzhankol lake, $50^{\circ} 49^{\prime} 03.83^{\prime \prime} \mathrm{N} 75^{\circ} 20^{\prime} 27.98^{\prime \prime} \mathrm{E}$, stony steppe, 27.06.2013, coll. D.A. Krivenko 48343 (MW), 51381, 51382 (IRK): 25.

\section{Thymus rasitatus Klokov (Labiatae)}

Contributors: Vladimir M. Vasjukov \& Denis Krivenko

\section{Distribution and habitat}

Th. rasitatus was described from the Kazakhstan, BektauAta Mount (LE! - Klokov 1954a) and has been considered so far endemic to East Kazakhstan (Klokov 1954a, b, 1973, Gamayunova \& Dmitrieva 1964). Here, for the first time, the species gives the locality for Russia from Altai. Th. rasitatus grows on stony steppe slopes and granite talus.

\section{Taxonomic notes}

Th. rasitatus belongs to the section Kotschyani (Klokov \& Des.-Shost.) Klokov, which includes shrubs with highly lignified and heavily branched stems (boles) topped with generative shoots.

In Altai, there is another species from the same section Th. roseus Schipcz., the area of which is located in the southeast of Western Siberia, in Eastern Kazakhstan and Western Mongolia (?).

For Th. rasitatus, unlike Th. roseus, generative shoots are $3-8 \mathrm{~cm}$ long rather than $1-2.5 \mathrm{~cm}$, mid-stem leaves are narrowly oblong-elliptic (4-10 $\mathrm{mm}$ long, 1-2 mm wide) rather than obovate or oblong-ovate, spatulate (4-9 $\mathrm{mm}$ long, $1.75-3.5 \mathrm{~mm}$ wide), petioles of lower stem leaves are equal to leaf blades rather than shorter than half of leaf blades, inflorescences are loose rather than dense, pedicels are $1.5-4 \mathrm{~mm}$ long rather than short (up to $1.5 \mathrm{~mm}$ long), and corollas are pinkish-lilac, not bright rather than lilac-pinkish or whitish, pale.

\section{Examined specimens (new records)}

RUSSIA: Altai Republic, Ongudaisky District, valley of Bolshoi Yaloman River, $6 \mathrm{~km}$ above of Yaloman village, $1500 \mathrm{~m}$ a.s.l., [50²8'20.85"N 86¹9'48.19"E], southern stony slope, 15.07.1972, coll. V. Makarov \& N. Alyanskaya 58293 (IRK): 26.

\section{Tulipa mongolica Y.Z. Zhao (Liliaceae)}

Contributors: Alexey V. Grebenjuk, Olga A. Chernysheva \& Lyudmila I. Sarajeva

\section{Distribution and habitat}

To date T. mongolica has been considered as endemic to Inner Mongolia (China), with only locality in the Xilingol Aimag/ League (Xilin Gol or Shiliin Gol) along the sandy fault of the volcanic cone. Currently, the species has apparently disappeared in a typical locality due to strong grazing (Zhao 2003).

In 2008, Grebenjuk (2008) assumed that Daurian tulips (uniflora-like) do not belong to any of two similar species known to Russia (T. uniflora (L.) Besser ex Baker and T. heteropetala Ledeb.) and probably are T. mongolica which had been recently described by Y.Z. Zhao (2003) from China. Shortly after the publication Grebenjuk obtained digital images of original material of T. mongolica (holo-, iso- and paratypes - HIMC) for comparison with few specimens collected in the Transbaikal Territory and previously identified as T. uniflora (Vlassova 1987). In 2010, these old herbarium specimens stored under the name T. uniflora in the Herbarium of the Komarov Botanical Institute RAS (LE), the Krylov Herbarium of the Tomsk State University (TK) and the Popov Herbarium of the Central Siberian Botanical Garden SB RAS (NSK), was revised as T. mongolica (LE, TK, NSK) by Grebenjuk. Therefore, this species was first collected by Radde in the territory of modern Russia in 1856 on the northern vicinities of Torey Nor Lake near the Kulusutay military base (Fig. 3). 
New localities of T. mongolica were recorded for the first time for Russia in the Transbaikal Territory. This species grows in grass steppe communities on the mountain slopes, on gravelly places, among petrophytic vegetation on rocky slopes, and in herbaceous cover of Armeniaca sibirica (L.) Lam. open shrublands. Most likely it also occurs in Mongolian part of the Torey lacustrine depression. Specimens from Mongolia are not known, but the occurrence of this species in the north-east of this country is highly probable.

\section{Taxonomic notes}

T. mongolica belongs to the separate subgenus Orithyia (D. Don) Baker. There are only few species in the subgenus Orithyia and they are mainly distributed in Altai (T. uniflora and T. heteropetala), Siberia, Mongolia (T. uniflora), northwestern China (T. sinkiangensis Z.M. Mao and T. uniflora), and North Tian Shan (T. heterophylla (Regel) Baker). After general revision of genus, M.J.M. Christenhusz et al. (2013) concluded that T. mongolica is synonymous to T. uniflora. However, the original material of $T$. mongolica has not been investigated by these authors. We do not agree with this position since these two species are clearly distinguishable in nature and among our and available herbarium material. Morphological characters of T. mongolica are closest to those of T. heteropetala and T. uniflora. A common feature of these three species is the ovoid bulb, the membranes of which are hairy on the inside of the apex. Vegetative characters of T. mongolica and T. uniflora are similar: opposite or densely alternate leaf arrangement. Generative characters of T. mongolica and T. heteropetala are similar: stamen filaments in the middle wide; inner tepals have a lanceolate shape (the difference between length and width is $2-2.5$ times). In contrast to morphologically close species, T. mongolica has the following characteristics: stigmas usually are elevated above stamens; the length of the anthers is 2.5-3(5) times less than the filaments; the length of the first leaf exceeds the length of the pedicel by $2-3$ times.

\section{Examined specimens (new records)}

RUSSIA: [Zabaykalsky Territory], Mongolia Ross., Desertum Gobi inter fl. Onon et Argun, [prope] Kulus [sutay], 13.05.1856, coll. G. Radde s.n. (LE01044754, LE01044755); [Zabaykalsky Territory] Chita Region, Borzinsky District, vicinity of Zun Torey Lake, feathered poor grass steppe, 09.05.1948, coll. N.F. Tereshchenko, s.n. (TK004149); [Zabaykalsky Territory] Chita Region, Aginsky District, left bank of the Onon River, Malyi Bator mount, among the open shrublands of the siberian apricot, 06.05.1959, coll. E.I. Pavlov s.n. (TK004148, TK004150); [Zabaykalsky Territory] Chita Province, Onon District, Gydyrgun mount, 20.05.1969, coll. A. Leontiyev s.n. (NSK0070095); [Zabaykalsky Territory] Chita Province, Onon District, Torey Depression, near Gydyrgun mount, 16.06.1969, coll. A. Leontiyev s.n. (NSK0070096); Zabaykalsky Territory, Aginsky Buryat Okrug, Aginsky District, the right bank of the Onon River, $4 \mathrm{~km}$ WNW of the village of Nizhny Tsasuchey village, Maly Bator tract, steppe

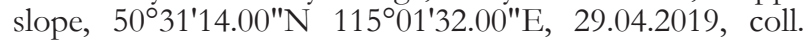
O.A. Chernysheva, L.I. Sarajeva, A.S. Erst, E.R. Khadeeva, D.A. Krivenko 53652, 53654 (IRK); Zabaykalsky Territory, Onon District, the vicinity of Gydyrgun mount near ZunTorey Lake, rocky steppe, 506'17.7"N 115³0'36.6"E, 21.05.2019, coll. L.I. Sarajeva s. n. (Herbarium of the Daursky State Nature Biosphere Reserve): 27-33.

\section{Verbesina encelioides (Cav.) Benth. et Hook f. ex A. Gray (Asteraceae)}

Contributors: Maxim Mallaliev \& Ramazan A. Murtazaliev Distribution and habitat

The natural area of the species covers Central and South America. It is sometimes cultivated as an ornamental plant, which contributes to its distribution and settlement in new places. For the Russian part of the Caucasus, the species is presented for the first time, however, the Plantarium (20072020) is provided data for the north of the Krasnodar Territory. It grows on weedy places, on sandy areas, in settlements along the roads.

\section{Taxonomic notes}

Belongs to the tribe Heliantheae, most of whose genera are characteristic to the America. The genus Verbesina L. has about 350 species. In the Caucasus from this genus only this species is wildly found.

\section{Examined specimens (new records)}

RUSSIA: Republic of Dagestan, Kaspiysk City, open meadow wet plot, 25.09.2019, M.M. Mallaliev (DAG, LE): 34.

\section{ACKNOWLEDGEMENTS}

The reported study was funded by RFBR according to the research projects №№ 17-44-388084, 19-04-00658, 19-2905205, 18-34-00090, 18-34-00551, 20-54-53008 GFEN_a, RFBR and Government of Irkutsk Region - grant 17-44388084, Institutional research project of the Komarov Botanical Institute, Russian Academy of Sciences, "Vascular Plants of Eurasia" (№ AAAA-A19-119031290052-1), Tomsk State University competitiveness improvement program, IWEP SB RAS No. 0383-2019-0004 and RFBR grant No. 19-05-50055-Microworld and the National Natural Science Foundation of China (3191101584).We thank Jennifer Poore, University of California Davis Center for Plant Diversity, for linguistic editing.

\section{LITERATURE CITED}

Anonymous 1976. Sparganium L. In: Flora Coreana, vol. 7 (Scientiarum R.P.D.C., eds.), pp. 31-32, Phyongyang. (in Korean).

Altinordu, F. \& P.P. Ferrer-Gallego 2016. Typifications of the Linnaean names Centaurea eriophora and $C$. orientalis (Asteraceae). Phytotaxa 277(1):97-100.

Baikov, K.S. (ed.) 2012. Conspectus of the flora of Asian Russia: vascular plants. Izdatel'stvo SO RAN, Novosibirsk, 640 pp. (in Russian). [Конспект фморы азиатской России: сосудистые растения / под реА. К.С. Байкова. 2012. Новосибирск: ИзА-во СО РАН. 640 с.].

Barkalov, V.Yu. 1992. Anthemis L. In: Vascular plants of the soviet Far East, vol. 6 (S.S. Kharkevich, ed.), pp. 92-94, Nauka, St. Petersburg (in Russian). [Баркалов B.Ю. 1992. Anthemis L. // Сосуаистые растения советского Аальнего Востока, т. 6/ под реА. С.С. Харкевича. СПб.: Наука. С. 92-94].

Bobrov, E.G. 1937. Adonis L. In: Flora of the USSR, vol. 7 (V.L. Komarov ed.), pp. 528-539, Izdatel'stvo AN SSSR, Moscow, Leningrad (in Russian). [Бобров Е.Г. 1937. Adonis L. / / ФАора СССР / под реА. Комаров В.А. М.; А.: Академия наук СССР. Т. 7. С. 528-539].

Bobrov, E.G. 1949. Geranium L. In: Flora of the USSR, vol. 14 (V.L. Komarov, ed.), pp. 2-62, Izdatel'stvo AN SSSR, Moscow, Leningrad (in Russian). [Бобров Е.Г. 1949. Geranium L. / Ф Фора СССР / под реА. В.А. Комарова.

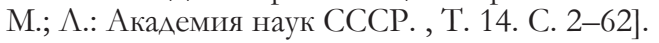

Busch, N.A. 1939. Alyssum L. In: Flora of the USSR, vol. 8 (V.L. Komarov, ed.), pp. 340-359, Izdatel'stvo AN SSSR, Moscow, Leningrad (in Russian). [Буш H.A. 1939. Alyssum L. // ФАора СССР / под реА. В.А. Комарова. М.; А.: ИзА-во АН СССР. Т. 8. С. 340.

CABI, 2020. Anthemis ruthenica. In: Invasive Species Compendium. Wallingford, UK: CAB International. Available from: 


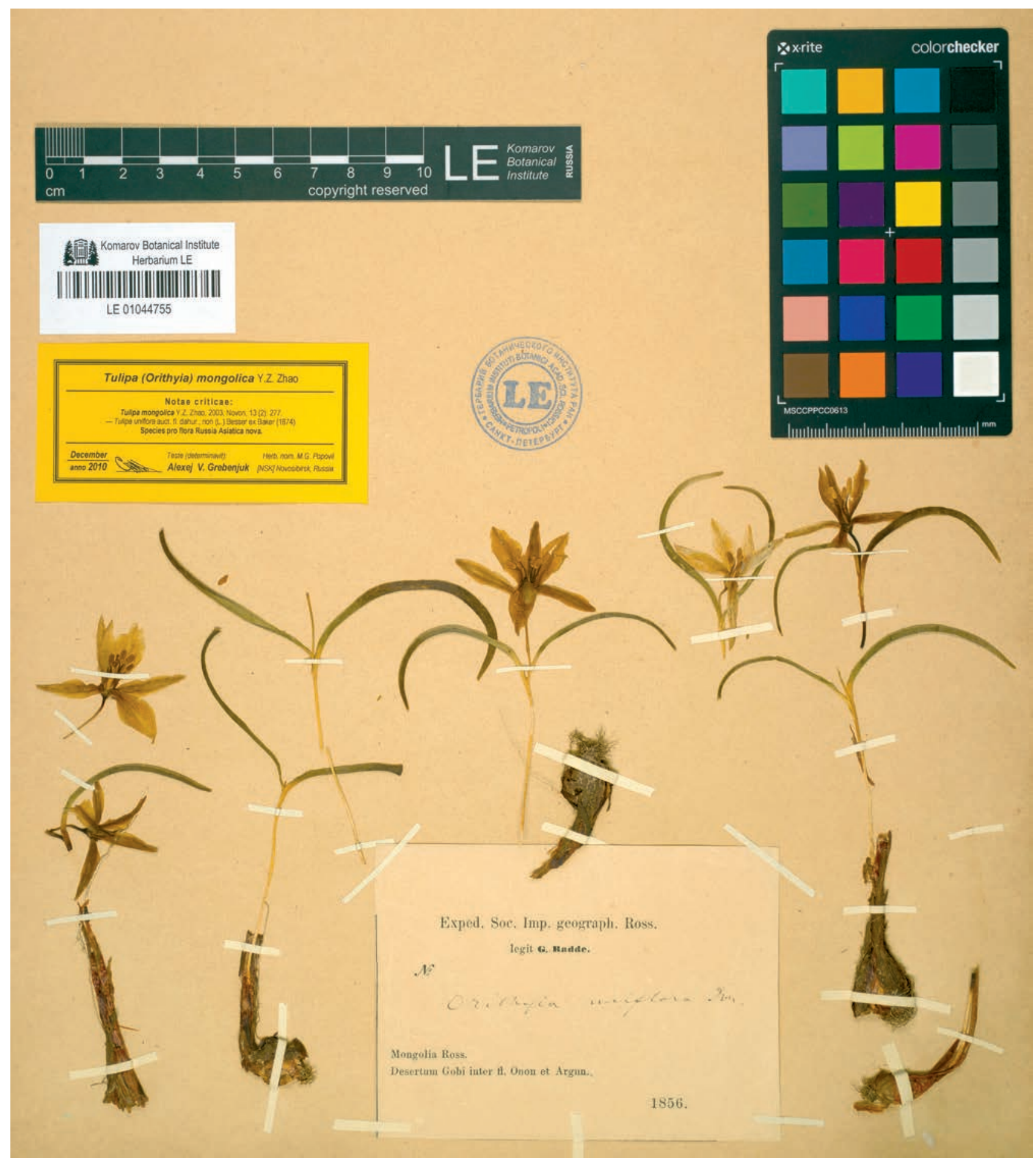

Figure 3 Oldest specimen defined by A.V. Grebenjuk as Tulipa mongolica Y.Z. Zhao collected by G. Radde in 13 May 1856 near Kulusutay (LE)

http:/ /www.cabi.org/isc/datasheet/112296. Last accessed 05.02.2020.

Chang, C.-S., H. Kim, \& K.S. Chang 2014. Provisional checklist of vascular plants for the Korea Peninsula flora (KPF) (Version 1.0). The DesignPost, Seoul, 660 pp.

Chang, K.S., D. Ch. Son, D.-H. Lee, K. Choi \& S.-H. Oh (eds) 2017. Checklist of vascular plants in Korea. Korea National Arboretum, Pocheon, 1000 pp.

Cherepnin, L.M. 1967. Flora of southern part of Krasnoyarsk Territory, vol. 6. Krasnoyarskiy rabochiy, Krasnoyarsk, 237 pp. (in Russian). [Черепнин А.М. 1967. ФАора южной части Красноярского края. Красноярск: Красноярский рабочий. Вып. 6. 237 с.].

Christenhusz, M.J.M., R. Govaerts, J.C. David, T. Hall, K. Borland, P.S. Roberts, A. Tuomisto, S. Buerki, M.W. Chase \& M.F. Fay 2013. Tiptoe through the tulips - cultural history, molecular phylogenetics and classification of Tulipa (Liliaceae). Botanical Journal of the Linnean Society 172:280-328.

Cook, C.D.K. \& M.S. Nicholls 1986. A monographic study of the genus Sparganium (Sparganiaceae). Part 1. Subgenus Xanthosparganium Holmberg. Botanica Helvetica 96(2): 213-267. 
Czerepanov, S.K. 1994. Centaurea L. In: Flora of the European part of the USSR, vol. 7 (N.N. Tzvelev, ed.), pp. 260-288, Nauka, Saint-Petersburg (in Russian). [Черепанов C.K. 1994. Василек - Centaurea L. // Фмора европейской части СССР, т. 7 / под реА. Н.Н. Цвелева. СПб. Наука. С. 260-288].

Dalke, I.V., E.G. Madi \& I.F. Chadin 2020. Occurrences of

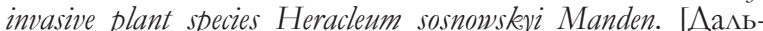
кэ И.В., Мади Е. Г., ЧаАин И. Ф. 2020. Распространение инвазивных вилов растений (на примере борщевика Сосновского]. Available from: URL: http://ib.komisc $\mathrm{ru} / \mathrm{add} / \mathrm{rivr}$. Last accessed 02.05.2020.

Dorofeyev, V.I. 2002. Cruciferae of European Russia. Turcraninowia 5(3):5-114 (in Russian). [Аорофеев В.И. 2002. Крестоцветные (Cruciferae Juss.) Европейской России // Turczaninowia. T. 5, № 3. C. 5-114].

Doronkin, V.M. 1997. Thymus L. In: Flora of Siberia: Pyrolaceae-Lamiaceae (Labiatae), vol. 11 (L.I. Malyschev, ed.), pp. 205-220, Nauka, Novosibirsk (in Russian). [Аоронькин B.M. 1997. Thymus L. // Фцора Сибири: Pyrolaceae-Lamiaceae (Labiatae) / под реА. А.И. Малышева. Новосибирск: Наука. Т. 11. С. 205-220].

Ebel, A.L. 2002. New data on distribution of Brassicaceae species in South Siberia and East Kazakhstan. Turczaninowia 5(2): 60-68 (in Russian). [Эбель А.А. Новые свеления о распространении крестоцветных (Brassicaceae) в Южной Сибири и Восточном Казахстане / Turczaninowia. 2002. T. 5, № 2. C. 60-68].

Ebel, A.L. 2013. New for Siberia and less known alien plant species. Sistematicheskie zametki po materialam Gerbariya imeni P.N. Krylova pri Tomskom gosudarstvennom universitete imeni V.V. Kuibysheva 108:23-28 (in Russian). [Эбель А. А. 2013. Новые Аля Сибири и малоизвестные чужеродные виды растений // Систематические заметки по материалам Гербария Томского государственного университета. № 108. С. 23-28].

Ebel, A.L., E.Yu. Zykova, S.I. Mikhailova, P.N Chernogrivov \& T.V. Ebel. 2018. Distribution and naturalization of the invasive species Heracleum sosnowsky Manden. (Apiaceae) in Siberia (in Russian). In: Ecology and geography of plants and plant communities: proceedings of the IV International Scientific Conference: proceedings of the IV International Scientific Conference Ekaterinburg, April 16-19, 2018). Izdatel'stvo Ural'skogo universiteta, Ekaterinburg, 1065-1070 pр. [Эбель А.А., Зыкова Е.Ю., Михайлова С.И., Черногривов П. Н., Эбель Т. В. 2018 Расселение и натурализация инвазивного вила Heracleum sosnowskyi Manden. (Apiaceae) в Сибири // Экомогия и география растений и растительных сообществ: материалы IV МежАународной научной конференции (Екатеринбург, 16-19 апреля 2018 г.). Екатеринбург: Иза-во Урам. ун-та. С. 1065-1070].

Ebel, A.L., S.I. Mikhailova, T.O. Strelnikova, S.A. Sheremetova, N.N. Lashchinskiy \& T.V. Ebel 2017. New and rare alien species for the Republic of Khakassia. Turczaninowid 20(1):52-67 (in Russian). [Эбель А.А., Михайлова С.И., Стрельникова Т.О., Шереметова С.А., Аащинский Н.Н., Эбель Т.В. 2017. Новые и релкие Аля Хакасии чужеродные виды растений // Turczaninowia. T. 20, № 1. C. 52-67].

Euro+Med. 2006-. Euro+Med PlantBase - the information resource for Euro-Mediterranean plant diversity. Published on the Internet: http://ww2.bgbm.org/EuroPlusMed/. Last accessed: 02.05.2020.

Fries, E.M. 1817. Flora Hallandica: Pars prior. Typis Berlingensis, Lund, 159 pp.
Fries, E.M. 1849. Summa vegetabilium Scandinaviae seu enumeratio, systematica et critica, plantarum tum cotyledonearum, quum nemearum, inter mare occidentale et album, inter Eidoram et Nordkap, bactenus lectarum, una cum singulae distributione geographica. Sectio posterior. Typographia Academica, Holmiae [Stockholm] \& Lipsiae [Leipzig], Upsaliae, pp. 259-572.

Gamayunova, A.P. \& A.A. Dmitrieva. 1964. Thymus L. In: Flora of Kazakhstan, vol. 7 (N.V. Pavlov, ed.), pp. 445-461, Izdatel'stvo AN KazakhSSR, Alma-Ata (in Russian). [Taмаюнова А.П., Амитриева А.А. 1964. Thymus L. // ФАора Казахстана / под реА. Н.В. Павлова. А^ма-Ата: ИзА-во АН КазахССР. , Т. 7. С. 445-461].

GBIF Secretariat. GBIF Backbone Taxonomy. https://doi. org/10.15468/39omei Accessed via https://www.gbif. org/species/

GBIF Secretariat 2019. Echinops sphaerocephalus L. In: GBIF Backbone Taxonomy. Checklist dataset available from: https://doi.org/10.15468/39omei accessed via gbif.org. Last accessed 02.05.2020.

GBIF Secretariat 2019. Silene dichotoma Ehrh. In: GBIF Backbone Taxonomy. Checklist dataset https://doi.org/ 10.15468/39omei accessed via GBIF.org on 2020-05-02.

German D.A. \& A.L. Ebel 2009. Some interesting finds of cruciferous (Cruciferae) in Asia. Sistematicheskie zametki po materialam Gerbariya imeni P.N. Krylova pri Tomskom gosudarstvennom universitete imeni V.V. Kuibysheva 101: 5-11 (in Russian). ГГерман А.А., Эбель А.А. Некоторые интересные находки крестоцветных (Cruciferae) в Азии // Систематические заметки по материалам Гербария им. П.Н. Крылова Томского государственного университета. 2009. № 101. С. 5-11].

Gerner, M., G. Nenadic \& C.M. Bergman 2010. LINNAEUS: a species name identification system for biomedical literature. BMC bioinformatics 11(85).

Gil, H.-Y., K.-H. Lee, Y.-H. Ha, Ch.-S. Jang \& D.-K. Kim 2019. Sparganium glomeratum (Typhaceae): A new record from South Korea. Korean Journal of Plant Taxonomy 49(4): 374-379.

Gilbert, C., J. Dempcy, C. Ganong, R. Patterson \& G.S. Spicer. 2005. Phylogenetic relationships within Phacelia subgenus Phacelia (Hydrophyllaceae) inferred from nuclear $r$ DNA ITS sequence data. Systematic Botany 30(3):627-634.

Gorshkova, S.G. 1953. Hydrophyllaceae Lindl. In: Flora of the USSR, vol. 19 (B.K. Shishkin, ed.), pp. 95-97. Izdatel'stvo Akademii nauk SSSR, Leningrad (in Russian). [Горшкова С.Г. 1953. Hydrophyllaceae Lindl. // Фмора СССР / под реА. Б.К. Шишкина. А.: ИзАательство Академии наук СССР. Т. 19. С. 95-97].

Grebenjuk, A.V. 2008. Note on Tulipa. In: Check-list of the vascular flora of the Irkutsk region (L.I. Malyshev ed.), pp. 90-91, Irkutsk State University Publ., Irkutsk (in Russian). [Гребенюк А.B. 2008. Tulipa - примечание // Конспект флоры Иркутской области (сосудистые растения) / под. ред. А. И. Малышева. Иркутск: ИзАво Иркут. гос. ун-та. С. 90-91].

Grebenjuk, A.V. 2012. Sparganium japonicum (Sparganiaceae) in the Far East. Botanicheskii Zhurnal 97(11):1406-1416 (in Russian). [Гребенюк A.B. 2012. Sparganium japonicum (Sparganiaceae) на Аальнем Востоке // Ботанический журнал. Т. 97, № 11. С. 1406-1416].

Greuter, W. 2011. Compositae (pro parte majore). In: Euro+Med Plantbase - the information resource for EuroMediterranean plant diversity. Available from: http://ww2. bgbm.org/EuroPlusMed /. Last accessed 05.02.2020). 
Grossheim, A.A. 1948. Onobrychis Adans. In: Flora of the USSR, vol. 13 (V.L. Komarov ed.), pp. 319-367, Izdatel'stvo AN SSSR, Moscow, Leningrad (in Russian). [Tpocсгем A.A. 1948. Onobrychis Adans. // ФАора СССР / под реа. В.А. Комарова. М.; А.: ИзА-во АН СССР. T. 13. C. 319-367].

Grossheim, A.A. 1949. Key to plants of Caucasus, Sovetskaya Nauka, Moscow, 747 pp. (in Russian). [Гроссгейм A.A. 1949. Определитель растений Кавказа. М.: Советская Наука. 747 с.].

Grossheim, A.A. 1952. Flora of the Caucasus, vol. 5. Izdatel'stvo AN SSSR, Moscow \& Leningrad, 740 pp. (in Russian). [Гроссгейм А.А. 1952. Фцора Кавказа. М.; А.: ИзА-во АН СССР. Т. 5.740 с.].

Hassler, M. 2019. World Plants: Synonymic Checklists of the Vascular Plants of the World (version Nov 2018). In: Species 2000 \& ITIS Catalogue of Life, 2019 Annual Checklist (Y. Roskov, G. Ower, T. Orrell, D. Nicolson, N. Bailly, P.M. Kirk, T. Bourgoi, R.E. DeWalt, W. Decock, E. van Nieukerken, J. Zarucchi, Penev L. eds). Species 2000: Naturalis, Leiden, the Netherlands. ISSN 2405884X. Available from:www.catalogueoflife.org/annualchecklist/2019. Last accessed 02.05.2020.

Hickman, J.C. (ed.) 1993. The Jepson Manual: Vascular Plants of California. University of California Press. 1424 p.

Hulten, E. \& M. Fries 1986. Atlas of North European Vascular Plants, North of the Tropic of Cancer, vol. 1-3. Konigstein. $1172 \mathrm{pp}$.

HYPPA: Hypermedia for Plant Protection. Available from: http://www2.dijon.inra.fr/hyppa/hyppa-a/antru_ ah.htm\# Ecological\%20profile. Last accessed 05.02.2020.

Ignatov, M.S. 2006. Anthemis L. In: Maevskii P.F. Flora of the middle zone of the European part of Russia. KMK Scientific Press, Moscow, 502 pp. (in Russian). [Игнатов M.C. 2006. Anthemis L. // Маевский П.Ф. ФАора средней полосы европейской части России. М.: Товарищество научных изАаний КМК. С. 502].

Ivanina, L.I. 1981. Cymbalaria Hill In: Flora of the European part of the USSR, vol. 5 (An.A. Fedorov ed.), p. 237, Nauka, Leningrad (in Russian). [Иванина А.И. Cymbalaria Hill // Фцора Европейской части СССР / под реА. Ан.А. Фёдорова. А.: Наука. Т. 5 С. 237].

Jahodová Š., L. Fröberg, P. Pyšek, D. Geltman, S. Trybush, \& A. Karp 2007. Taxonomy, identification, genetic relationships and distribution of large Heracleum species in Europe. In: Ecology and Management of Giant Hogweed (Heracleum mantegazzianum) (P. Pyšek, M.J.W. Cock, W. Nentwig \& H.P. Ravn, eds.), pp. 1-19, CAB International, Wallingford, UK, .

Jakovlev, G.P., A.K. Sytin \& Yu.R. Roskov 1996. Legumes of Northern Eurasia. Kew, 724 pp.

Junghans, T. \& E. Fischer 2008. Aspects of dispersal in Cymbalaria muralis (Scrophulariaceae). Botanische Jahrbücher für Systematik, Pflanzengeschichte und Pflanzengeographie 127: 289-298.

Kabuce N. \& N. Priede, 2010. NOBANIS - Invasive Alien Species Fact Sheet - Heracleum sosnowskyi. In: Online Database of the North European and Baltic Network on Invasive Alien Species - NOBANIS. URL: https://www.nobanis. org/ (date of access: 02.05.2020).

Kamelin, R.V. \& S.S. Kovalevskaya 1993. Anthemis L. In: Conspectus Florae Asiae Mediae, vol. 10 (Vvedensky, A.I. \& R.V. Kamelin, eds.). Tashkent, 517 pp. (in Russian). ГКамелин P.B., Ковалевская С.С. 1993. Anthemis L. // Опреде- митель растений Средней Азии. Ташкент. Т. 10. 571].

Kaul, R.B. 2000. Fam. Sparganiaceae Rudolphi. In: Flora of North America north of Mexico. Vol. 22 Magnoliophyta: Alismatidae, Arecidae, Commelinidae (in part), and Zingeberidae (Flora of North America Editorial Committee, ed.), pp. 270-277. Oxford University Press, Oxford, New York.

Keil D.J. Echinops Linnaeus. 2006. In: Flora of North America North of Mexico: Magnoliophyta: Asteridae, Part 6: Asteraceae, (Part 1), vol. 19 (Barkley T.M., L. Brouillet \& J.L. Strother, eds), p. 85, Oxford University Press, New York \& Oxford.

Kim, C. \& H.-K. Choi 2007. Sparganiaceae. In: The Genera of Vascular Plants of Korea (ed. by Flora of Korea Editorial Committee), pp. 1265-1267, Academy Publishing Co., Seoul.

Klokov M.V. 1926. About a new species of shepherd's bag growing within the Voronezh province. Bulletin of the Society of Naturalists at Voronezh State University 1(24) pp. 119-122. (in Russian). [К виле пастушьей сумки, произрастающей в пределах Воронежской губернии // Бюл. об-ва естествоисп. при Воронеж. гос. ун-те. 1926. Т. 1, № 2-4. С. 119$122]$.

Klokov, M.V. 1954a. New species of the genus Thymus L. in the USSR. Botanicheskie materialy Gerbariya Botanicheskogo instituta imeni V.L. Komarova AN SSSR 16:293-318 (in Russian). [Клоков М.В. 1954a. Новые виды рода Thymus L. в СССР // Ботанические материалы Гербария Ботанического института им. B.А. Комарова АН СССР. Т. 16. С. 293-318].

Klokov, M.V. 1954b. Thymus L. In: Flora of the USSR, vol. 21 (B.K. Shishkin, ed.), pp. 470-590, Izdatel'stvo AN SSSR, Moscow \& Leningrad (in Russian). [КАоков M.B. 1954b. Thymus L. // ФАора СССР, т. 21 / пол реА. Б.К.

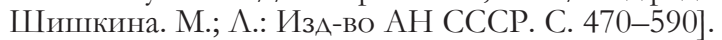

Klokov, M.V.1973. Race formation in genus Thymus L. on the territory of the Soviet Union. Naukova dumka, Kiev, 190 pp. (in Russian). [К роде тимьянов - Thymus L. на территории Советского Союза. Киев: Наукова Аумка. 190 с.].

Kozhevnikov, A.E. \& Z.V. Kozhevnikova. 2007. Flora of the Amur River basin (Russian Far East): taxonomic diversity and spatial change of taxonomic structure. Komarovkie Chtenya 55:104-183 (in Russian). [Кожевников A.E., Кожевникова 3.В. 2007. ФАора бассейна реки Амур (Российский Аальний Восток): таксономическое разнообразие и пространственные изменения таксономической структуры // Комаровские чтения. Вып. 55. С. 104-183].

Kozhevnikov, A.E. 1991. Hydrophyllaceae R. Br. ex Edwards. In: Vascular plants of Soviet Far East, vol. 5 (S.S. Kharkevich, ed.), pp. 253-254, Nauka, St. Petersburg (in Russian). [Кожевников A.E. 1991. Hydrophyllaceae R. Br. ex Edwards / / Сосудистые растения советского Аальнего Востока. Спб.: Наука. С. 253-254].

Krasnoborov, I.M., ed.) 2001. Key to plants of Kemerovo Region. Nauka, Novosibirsk, 477 pp. (in Russian). [ОпреАелитель растений Кемеровской области / под реА. И.М. Красноборова. Новосибирск: ИзА-во СО РАН, 2001. 477 c.].

Krylov, P.N. 1931. Silene L. In: Flora of Western Siberia, vol. 5. pp. 1049-1071, Tomsk (in Russian). [Крылов П.Н. 1931. Silene L. // Фцора Западной Сибири. Томск. Т. 5. C. 1049-1071].

Kulikov P.V. 2005. Synopsis of flora of the Chelyabinsk Region (vascular plants). Geotour, Ekaterinburg, Miass, 537 pp. (in Russian). [Куликов П.В. 2005. Конспект флоры Челя- 
бинской области (сосудистые растения). Екатеринбург; Миасс: Геотур. 537 с.]

Kun, S. \& D.A. Simpson 2010. Sparganium Linnaeus. In: Flora of China, vol. 23: Acoraceae through Cyperaceae (Z.Y. Wu, P.H. Raven \& D.Y. Hong, eds), pp.158-161, Science Press, Missouri Botanical Garden Press, Beijing, St.-Louis.

Kupriyanov, A.N., I.A. Khrustaleva \& A.L. Ebel 2015. Floristic records in the Central Kazakhstan. Sistematicheskie zametki po materialam Gerbariya imeni P.N. Krylova pri Tomskom gosudarstvennom universitete imeni $V$.V. Kuibysheva 112:14-21 (in Russian). [Куприянов А.Н., Хрусталева И.А., Эбель А.А. 2015. ФАористические находки в Центральном Казахстане / / Систематические заметки по материалам Гербария Томского государственного университета. № 112. С. 14-21].

Kuzmin, I.V. 2008. Sosnowsky's hogweed (Heracleum sosnowskyi Manden.) in the Tyumen Region. In: VI Zyryanov readings: materials of the All-Russian scientific-practical conference (Kurgan, December 11-12, 2008), 168-169 pp. Izdatel'stvo Kurganskogo universiteta, Kurgan (in Russian). [Кузьмин И.В. 2008. Борщевик Сосновского (Heracleum sosnowskyi Manden.) в Тюменской области // VI Зыряновские чтения: материалы Всеросс. научнопракт. конф. (г. Курган, 11-12 декабря 2008 г.). Курган: Иза-во Курганского гос. ун-та. С. 168-169].

Lazkov, G. \& A. Sennikov 2014. New records in vascular plants alien to Kyrgyzstan. Biodiversity Data Journal2: e1018.

Lee, T.B. 1980. Illustrated Flora of Korea. Hyangmun Co., Seoul, 990 pp. (in Korean).

Lee, Y.N. 1996. Flora of Korea. Kyo-Hak Publishing Co., Seoul, 1247 pp. (in Korean).

Mayorov, S.R, V.D. Bochkin, Yu.A. Nasimovich \& A.V. Scherbakov 2012. Adventive flora of Moscow and the Moscow Region. KMK Scientific Press, Moscow, 412 pp. (in Russian). [Майоров C.P., Бочкин В.А., Насимович Ю.А., Щербаков А.В. ААвентивная фцора Москвы и Московской области. М.: Товарищество научных изАаний КМК, 2012. 412 с.].

Mandenova I. 1944. Fragments of the monograph of Caucasian Hogweeds. Zametki po sistematike i geografii rastenii 12 13-19 (in Russian). Манденова И. 1944. Фрагменты монографии кавказских борщевиков // Заметки по систематике и географии растений, Вып. 12. С. 13-19].

Mandenova I.P. 1951. Heracleum L. In: Flora of the USSR, vol. 17 (B.K. Shishkin, ed.), pp. 223-259, Izdatel'stvo AN SSSR, Moscow, Leningrad (in Russian). Манденова И.П. 1951. Heracleum L. / / ФАора СССР, т. 17 / под реА. Б.К Шишкина. М.; А.: ИзА-во АН СССР. С. 223-259].

Marhold, K. 2011. Caryophyllaceae. In: Euro+Med Plantbase - the information resource for Euro-Mediterranean plant diversity. http://ww2.bgbm.org/EuroPlusMed/. Last accessed 05.03.2020).

Mayorov, S.R. 2014. Scrophulariaceae Juss. In: Maevskit P.F. Flora of the middle zone of the European part of Russia (V.S. Novikov, V.N. Pavlov, D.D. Sokolov, A.K. Timonin, Yu.E. Alekseev \& C.R. Mayorov, eds), pp. 395-411, KMK Scientific Press, Moscow (in Russian). [Майоров C.P. 2014. Scrophulariaceae Juss. // Маевский П.Ф. ФАора средней полосы европейской части России / поА реА. В.С. Новикова, В.Н. Павлова, А.А. Соколова, А.К. Тимонина, Ю.Е. Алексеева, С.Р. Майорова. М.: Товарищество научных изданий КМК. С. 395-411].

Menitsky Ju.L. 2001. Synopsis of caucasian species of Onobrychis (Fabaceae). Botanicheskii Zhurnal 86(10): 75-88 (in
Russian). [Менитский Ю.А. 2001. Конспект кавказских видов Onobrychis (Fabaceae) // Ботанический журнац. T. 86, № 10. С. 75-88].

Morton, J.K. 2005. Silene L. In: Flora of North America, vol. 5. Magnoliophyta: Caryophyllidae, part 2 (ed. by Flora of North America Editorial Committee), pp. 167-214. Oxford University Press, New York, Oxford.

Naumenko, N.I. 2008. Flora and vegetation of Southern Zauralye. Kurgan: Kurgan University Press, 512 pp. (in Russian). [Науменко Н.И. 2008. ФАора и растительность южного Зауралья. Курган: ИзА-во Курганского ун-та. 512 с.].

Nielsen C., H.P. Ravn, W. Nentwig \& M. Wade (eds.). 2005. The Giant Hogweed Best Practice Manual. Guidelines for the management and control of an invasive weed in Europe. Forest and Landscape Denmark, Hoersholm, 44 p.

Novoselova, M.S. 1999. Family Geraniaceae in the flora of Russian Far East. Botanicheskii Zhurnal 84(5): 127-135 (in Russian). [Новоселова М.С. 2007. Семейство Geraniaсеае во фморе Российского Аальнего Востока / / Ботанический журнал. Т. 84, № 5. С. 127-135].

Ohwi, J. 1965. Flora of Japan (F. G. Meyer \& E. H. Walker, eds.), Smithsonian Institution, Washington, 1067 pp.

Peshkova, G.A. 1996. Geranium L. In: Flora of Siberia, vol. 10 (L.I. Malyschev, ed.), pp. 8-21, Nauka, Novosibirsk (in Russian). Пешкова Г.А. 1996. Geranium L. // ФАОра Сибири, т. 10 / под реА. А.И. Малышева. Новосибирск: Наука. С. 8-21].

Pimenov M.G. \& Ostroumova T.A. 2012: Umbelliferae of Russia. KMK Scientific Publishing Co, Moscow, 477 pp. (in Russian with English summary). [Пименов М.Г., Остроумова Т.А. 2002. Зонтичные (Umbelliferae) России. Москва: Товарищество научных изданий КМК. 477 с.].

Plantarium: open on-line atlas and key to plants and lichens of Russia and neighbouring countries. 2007-2020. Verbesina encelioides (Cav.) Benth. \& Hook. f. ex A. Gray. Available from: https://www.plantarium.ru/page/view/ item/50509.html. Last accessed 02.05.2020.

Poluyanov, A.V. \& E.A. Sklyar 2015. Additions and corrections to the flora of Kursk Province based on records of 2014. Byulleten' Moskovskogo Obshchestva Ispytatelei Prirody, Otdel Biologicheskii 120(3):63-64 (in Russian). [Полуянов А.В., Скцяр Е.А. 2015. Аополнения и уточнения к фморе Курской области по материалам 2014 года / / Бюмлетень МОИП. ОтАем биологический. Т. 120, вып. 3. С. 63-64].

POWO. 2019. Plants of the World Online. Facilitated by the Royal Botanic Gardens, Kew. Published on the Internet: http://www.plantsoftheworldonline.org/. Retrieved: 08.04.2020.

Revushkin, A.S. (ed.) 2014. Key to plants of Tomsk Region. Tomsk State University, Tomsk, 464 pp. (in Russian). [Определитель растений Томской области / пол реА. А.С. Ревушкина. Томск: ИзА-во Том. ун-та, 2014. 464 с.].

Ryff, L. 2019: Amaranthus viridis L. P. 96 in: Raab-Straube E. von \& Raus Th. (ed.), Euro+Med-Checklist Notulae, 10 [Notulae ad floram euro-mediterraneam pertinentes No. 39]. Willdenowia 49: 95-115.

Scheglova, I. 2018. Image of Phacelia tanacetifolia Benth. Plantarium: open on-line atlas and key to plants and lichens of Russia and neighbouring countries. 2007-2020. https://www. plantarium.ru/page/image/id/580889.html

Sergievskaya, L.P. 1956. Some new species from Western Siberia. Sistematicheskie zametki po materialam Gerbariya 
imeni P.N. Krylova pri Tomskom gosudarstvennom universitete imeni V.V. Kuibysheva 79-80:5-9 (in Russian). [Сергиевская А.П. 1956. Несколько новых видов из Западной Сибири // Систематические заметки по материалам Гербария им. П.Н. Крылова при Томском государственном университете им. В.В. Куйбышева. № 79-80. C. 5-9].

Shaulo D.N. \& E.Yu. Zykova 2013. Findings of adventive species in the Novosibirsk Province. Rastitel'nyi mir Asiatskoi Rossii 1(11): 37-43 (in Russian). Шауло А.Н., Зыкова Е.Ю. 2013. Находки адвентивных видов в Новосибирской области // Растительный мир Азиатской России. № 1(11). С. 37-43].

Silantieva, M.M., A.I. Shmakov \& S.V. Smirnov 2005. Addition to the flora of the Altai Republic and Altai Territory. Turczaninowia 8(4):36-40 (in Russian). [Симантьева M.M., Шмаков А.И., Смирнов С.В. 2005. Аополнение к флорам Республики Алтай и Алтайского края / / Turczaninowia. T. 8, № 4. C. 36-40].

Silantieva, M.M., A.L. Ebel \& T.V. Ebel 2003. Floristic findings in Altai District (Altaisky Krai). Turczaninowia 6(2):42-50 (in Russian). [Силантьева М.М., Эбель А.А., Эбель Т.В. 2013. Фмористические находки в Алтайском районе А^тайского края // Turczaninowia. Т. 6, № 2. C. 42-50].

Sokolov, V.S., I.B. Sandina \& G.M. Balabas 1965. New silage plants and the possibilities of their cultivation in Siberia. In: Plant resources of Siberia, the Urals and the Far East, pp. 249-253, Novosibirsk (in Russian). [Соколов B.C., Сандина И.Б., Балабас Г.М. 1965. Новые силосные растения и возможности их выращивания в Сибири // Растительные ресурсы Сибири, Урала и Аальнего Востока. Новосибирск. С. 249-253].

Szczęśniak, E. \& K. Świerkosz 2003. Cymbalaria muralis P. Gaertn., B. Mey. \& Schreb. and Cymbalarietum muralis Görs 1966 in Lower Silesia - expansion or regression? Phytogeographical problems of synanthropic plants, 185-193.

Tamamshyan, S.G. 1959. Conyzanthus Tamamsch. In: Flora of the USSR, vol. 25 (B.K. Schischkin, ed.), p. 186, Izdatelstvo AN SSSR, Moscow, Leningrad (in Russian) (in Russian). (Тамамшян С.Г. 1959. Conyzanthus Tamamsch. / / Фцора СССР / под ред. Б.К. Шишкина. М.; А.: ИзА-во АН CCCP. T. 25. C. 186).

Terskikh R.S. 1977. The study of new forage crops. In: Agrotechnology, selection and seed production of grain and forage crops in Eastern Siberia, pp. 63-79, Irkutsk Agricultural Institute, Irkutsk (in Russian). [Терских Р.С. 1977. Изучение новых кормовых культур // Агротехника, селекция и семеноводство зерновых и кормовых культур в Восточной Сибири. Иркутск: Иркутский сельскохозяйственный институт. С. 63-79].

The Plant List. 2013. The Plant List. Version 1.1. Published on the Internet: http://www.theplantlist.org/. Accessed: 08.04.2020.

Tojibaev, K.Sh., N.Yu. Beshko, A.R. Batashov, F.I. Karimov, Dong-Hyuk Lee, O.T. Turginov, M.X. Usmonov, U.H. Kodirov \& D. Tajeddinova 2017. Ten new records of vascular plants for the flora of Uzbekistan (Asteraceae). Korean Journal of Plant Taxonomy 47(3): 171-179.

Tsyrenova, D.Yu. 2007. Genus Geranium L. in the Amur River basin. Systematics, distribution, phylogeny. Far Eastern State University of Humanitices, Khabarovsk, 182 pp. (in Russian). ЦЦыренова А.Ю. 2007. Герани (Geranium, Geraniaceae) в бассейне Амура. Систематика, распространение, фимогения. Хабаровск: ИзА-во АВГГУ. 182 с.].
Turland, N.J., J.H. Wiersema, F.R. Barrie, W. Greuter, D.L. Hawksworth, P.S. Herendeen, S. Knapp, W.-H. Kusber, D.Z. Li, K. Marhold, T.W. May, J. McNeill, A.M. Monro, J. Prado, M.J. Price \& G.F. Smith (eds.) 2018. International Code of Nomenclature for algae, fungi, and plants (Shenzhen Code) adopted by the Nineteenth International Botanical Congress Shenzhen, China, July 2017. Regnum Vegetabile 159, Koeltz Botanical Books, Glashütten, 254 pp.

Tzvelev N.N. 1959. Galatella Cass. In: Flora of the USSR, vol. 25 (B.K. Schischkin, ed.), pp. 138-172, Izdatelstvo AN SSSR, Moscow, Leningrad (in Russian). [Цвелев Н.H. 1959. Galatella Cass. // ФАора СССР / ПоА реА. Б.К. Шишкина. М.; А.: ИзА-во АН СССР. Т. 25 С. 138-172].

Tzvelev N.N. 2010. On the genus Koeleria Pers. (Poaceae) in Russia. Novosti sistematike yysshykh rastenii 42:63-90 (in Russian). [Цвелев Н.Н. 2010. О роде Тонконог (Koeleria Pers., Роасеае) в России // Новости систематики высших растений. Т. 42. С. 63-90].

Tzvelev, N.N. 1963. Centaurea L. subgenus Lopholoma (Cass.) Spach. In: Flora of the USSR, vol. 28 (E.G. Bobrov \& S.K. Czerepanov, ed.), pp. 493-512, Izdatelstvo AN SSSR, Moscow, Leningrad (in Russian). [Цвелев H.H. 1963. Centaurea L. subgenus Lopholoma (Cass.) Spach // Фムopa СССР / под реА. Е.Г. Боброва и С.К. Черепанова. М.; А.: Иза-во АН СССР. Т. 28. С. 493-512].

Tzvelev, N.N. 1989. Persicaria Mill. In: Vascular plants of the soviet Far East, vol. 4 (S.S. Kharkevich, ed.), pp. 63-79, Nauka, Leningrad (in Russian). Цвелев H.H. 1989. Persicaria Mill. // Сосудистые растения советского Аальнего Востока / под ред. С.С. Харкевича. А: Наука. Т. 4 С. 63-79].

Tzvelev, N.N. 1994. Anthemis L. In: Flora of the European part of the USSR, vol. 7 (N.N. Tzvelev, ed.), pp. 106-113, Nauka, St. Petersburg (in Russian). [Цвелев H.H. 1994. Anthemis L. // ФАора Европейской части России. СПб.: Наука. Т. 7. С. 106-113].

Tzvelev, N.N. 1994. Galatella Cass. In: Flora of the European part USSR, vol. 7 (N.N. Tzvelev, ed.), pp. 189-194, Nauka, Saint-Petersburg (in Russian). [Цвемев H.H. 1994. Galatella Cass. // ФАора европейской части СССР / поА рел. Н.Н. Цвелева. СПб̆.: Наука. Т. 7. С. 189-194].

Tzvelev, N.N. 1996. Persicaria Mill. In: Flora of East Europe, vol. 9 (N.N. Tzvelev, ed.), pp. 125-132, Nauka, St. Petersburg (in Russian). [Цвелев Н.H. 1996. Горец - Persicaria Mill. // Фцора Восточной Европы. СПб.: Наука. Т. 9. C. 125-132].

Tzvelev, N.N. 1996. Sparganium L. In: Vascular plants of the soviet Far East, vol. 8 (S.S. Kharkevich, ed.), pp. 346-354, Nauka, St. Petersburg (in Russian). [Цвелёв Н.H. 1996. Род Ежеголовник - Sparganium L. // Сосудистые растения советского АаАьнего Востока / под реА. С.С. Харкевича. СПб.: Наука. Т. 8. С. 346-354].

Tzvelev, N.N. 2008. Conyzanthus Tamamsch. In: Conspectus of the flora of Caucasus, vol. 3(1) (A.L.Takhtajan, ed.), p. 176, Izdatel'stvo Sankt-Peterburgskogo universiteta, St. Petersburg (in Russian). [Цвелев H.H. 2008. Conyzanthus Tamamsch. // Конспект флоры Кавказа / под. реА. А. А. Тахтаджяна. СПб.: ИзА-во СПбГУ. Т. 3(1). С. 176].

Ueda K. 2020. iNaturalist Research-grade Observations. iNaturalist. org. Occurrence dataset https:/ / doi.org/10.15468/ab3s5x accessed via GBIF.org on 2020-05-02. https://www.gbif. org/occurrence/2331913702.

Vasilchenko I.T. 1939. Capsella Medik. In: Flora of the USSR, vol. 8, pp. 603-605 (in Russian). [Васильченко И.Т. 1939. Род Пастушья сумка - Capsella Medik. // ФАора СССР. М.; $\Lambda .:$ Иза-во АН СССР. Т. 8. С. 603-605]. 
Verkhozina, A.V., V.N. Belous, O.A. Chernysheva, A.L. Ebel, A.S. Erst, N.V. Friesen, M.A. Iuzhakova, A.A. Kuznetsov, A.N. Luferov, V.V. Murashko, R.A. Murtazaliev, S.V. Ovchinnikova, Wei Wang, O.Yu. Zavgorodnyaya, A.Yu. Korolyuk, S.A. Senator, E.G. Zibzeev, V.M. Vasjukov \& D.A. Krivenko 2019. Findings to the flora of Russia and adjacent countries: New national and regional vascular plant records, 1. Botanica Pacifica. A journal of plant science and conservation, 8(1): 143-154.

Vinogradova, Yu.K, S.R. Mayorov \& L.V. Khorun. 2010. Black book of the Central Russia: alien plant species in ecosystems of the Central Russia. GEOS, Moscow, 512 pp. (in Russian). [Виноградова Ю.К., Майоров С.Р., Хорун А.В. 2010. Черная книга Средней России: чужеродные виды растений в экосистемах СреАней России. Москва: ГЕОС. 512 c.].

Vinogradova, Yu.K., E.V. Aistova, L.A. Antonova, O.A. Chernyagina, E.A. Chubar, G.F. Darman, E.A. Devyatova, M.G. Khoreva, O.V. Kotenko, E.A. Marchuk, E.G. Nikolin, S.V. Prokopenko, T.A. Rubtsova, V.V. Sheiko, E.P. Kudryavtseva \& P.V. Krestov 2020. Invasive plants in flora of the Russian Far East: the checklist and comments. Botanica Pacifica 9(1). DOI: 10.17581/bp.2020.09107

Vlassova, N.V. 1987. Tulipa L. In: Flora of Siberia: AraceaeOrchidaceae, vol. 4 (L.I. Malyshev \& G.A. Peshkova, eds), pp. 102-103, Nauka, Novosibirsk (in Russian). BAacoва Н.B. 1987. Tulipa L. // Фмора Сибири: Araceae-Orchidaceae / под реА. А.И. Малышева и Г.А. Пешковой. Новосибирск: Наука. С. 102-106].

Walden, G.K. \& R. Patterson. 2012. Nomenclature of subdivisions within Phacelia (Boraginaceae: Hydrophylloideae). Madroño 59(4): 211 -222.

WCVP. 2020. World Checklist of Vascular Plants, version 2.0. Facilitated by the Royal Botanic Gardens, Kew. Available from: http://wcvp.science.kew.org/. Last accessed 08.04.2020.

Webb, D.A. 1972. Cymbalaria Hill In: Flora Europaea: Diapensiaceae to Myoporaceae, vol. 3 (T.G. Tutin, V.H. Hey- wood, N.A. Burges, D.M. Moore, D.H. Valentine, S.M. Walters \& D.A. Webb, eds.), pp. 236-237, Cambridge University Press, Cambridge.

Wiggins, I.L. 1980. Flora of Baja California. Stanford University Press. 1025 pp.

Yakovlev, G.P., A.K. Sytin \& Yu.R. Roskov 1996. Legumes of Nothern Eurasia: A checklist. Royal Botanic Gardens, Kew, 724 pp.

Zhao, Y.Z. 2003. A new species of the genus Tulipa (Liliaceae) from China. Novon 13(2):277-278.

Zhirova, O.S. 1997. Echinops L. In: Flora of Siberia: Asteraceae, vol. 13 (I.M. Krasnoborov, ed.), pp. 174-178, Nauka, Novosibirsk, (in Russian). [Жирова O.C. 1997. Echinops L. // ФАора Сибири: Asteraceae, Т. 13 / под реА. И.М. Красноборова. Новосибирск: Наука. С. 174-178].

Zolotukhin, N. I. 1983. Adventive plants in the Altai Reserve. Botanicheskii Zhurnal 68(11):1528-1533. (in Russian). [Золотухин Н.И. ААвентивные растения на территории А^тайского заповедника // Ботанический журнал. 1983. Т. 68, № 11. С. 1528-1533].

Zuev, V.V. 1993. Silene L. In: Flora of Siberia: PortulacaceaeRanunculaceae, vol. 6 (L.I. Malyschev \& G.A. Peshkova, eds.), pp. 62-71, Nauka, Novosibirsk (in Russian). [Зуев B.B. 1993. Silene L. / / Фмора Сибири: Portulacaceae - Ranunculaceae / пол реА. А.И. Малышева, Г.А. Пешковой. Новосибирск: Наука. Т. 6. С. 62-71].

Zykova, E.Yu. 2015. Adventive flora of the Altai Republic. Rastitel'nyi mir Asiatskoi Rossii 3(19):72-87 (in Russian). [Зыкова Е. Ю. 2015. ААвентивная флора Республики А^тай // Растительный мир Азиатской России. № 3(19). C. 72-87].

Zykova, E.Yu. 2016. Heracleum sosnowskyi Manden. In: Black book of Siberian Flora (A.N. Kupriyanov ed.), pp. 96-102, Geo, Novosibirsk (in Russian). [Зыкова Е.Ю. 2016. Heracleum sosnowskyi Manden. - Борщевик Сосновского // Чёрная книга флоры Сибири / под реА. А.Н. Куприянова. Новосибирск: Гео. С. 45-56]. 